\title{
Il secondo concorso per il Parlamento di Ernesto Basile. Criteri di modellazione e stampa 3D
}

Fabrizio Avella

Abstract

II progetto per il secondo concorso per il Parlamento di Ernesto Basile, premiato nel I890, si configura come opera di grande pregio nella produzione dell'architetto palermitano e come preziosa testimonianza per la storia dell'architettura e la storia del disegno.

I disegni originari, conservati presso la Dotazione Basile del Dipartimento di Architettura dell'Università degli Studi di Palermo, già oggetto di studio e di analisi, sono stati utilizzati per una ulteriore elaborazione finalizzata alla realizzazione di un modello in stampa 3D in scala 1:100 che sarà in esposizione permanente presso la Dotazione stessa.

II presente studio ne descrive il processo metodologico, i criteri di realizzazione ed i risultati raggiunti.

Parole chiave

Ernesto Basile, modellazione digitale, stampa 3d.

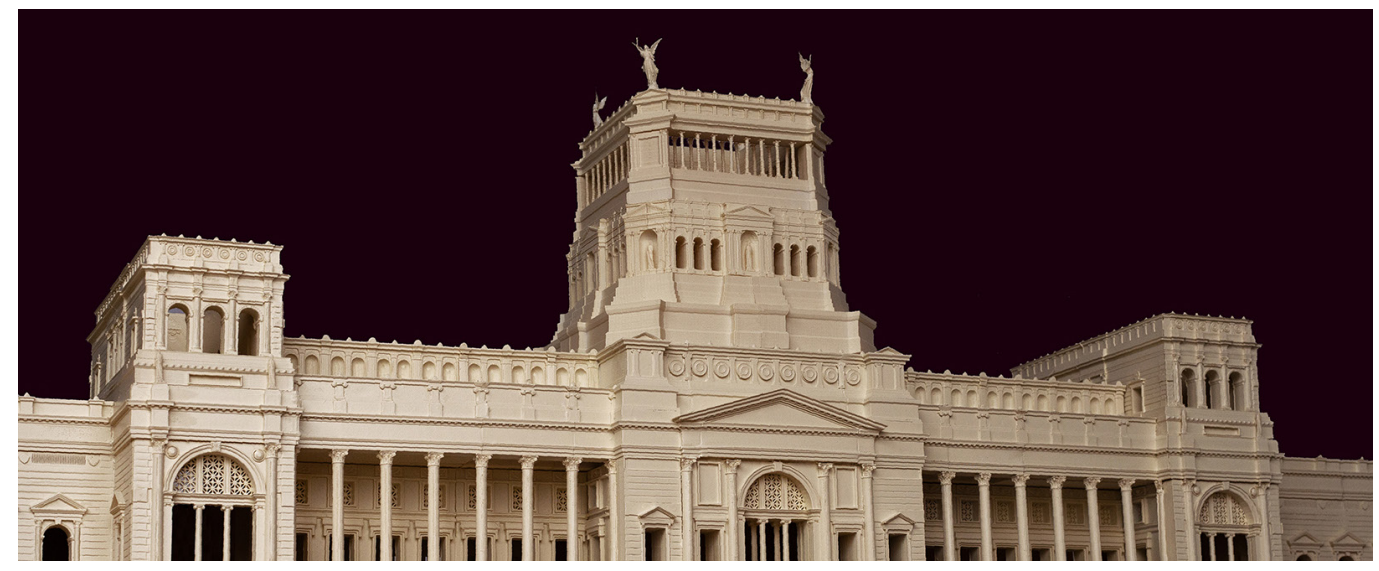




\section{Introduzione}

II progetto per il secondo concorso per il Parlamento del Regno d'Italia, redatto tra il I888 ed il I889 vede come vincitore ex aequo [I] il giovane Ernesto Basile (Palermo I 857- 1932), che si era già cimentato con il concorso per il Palazzo di Giustizia di Roma, svoltosi tra il I 884 ed il | 887, vinto da Guglielmo Calderini.

II progetto non sarà realizzato, a causa della Caduta del Governo Crispi del I89 I, ma Basile sarà chiamato ad elaborare il progetto per l'ampliamento del palazzo di Montecitorio tra il 1903 ed il 1918, realizzando il progetto per il corpo di fabbrica contenente la Camera dei Deputati, tutt'oggi esistente, da considerarsi "una sorta di gemmazione, dall'organismo del suo secondo Palazzo del Parlamento" [Mauro, Sessa 2000b, p. 4I].

I disegni sono conservati presso la Dotazione Basile delle Collezioni Scientifiche del Dipartimento di Architettura dell'Università degli Studi di Palermo, curato dal Professore Ettore Sessa. Un primo studio di ricostruzione congetturale dell'opera è stato già pubblicato [Avella 2020, pp. 1622-1643] e si rimanda a quel testo per i criteri di interpretazione, vettorializzazione, modellazione e analisi grafica. In questa sede si riportano le fasi del processo necessarie alla rimodulazione del modello tridimensionale ed all'ottimizzazione necessaria alla realizzazione di un modello in PLA in scala I:I00.

\section{Analisi delle fonti e criteri di modellazione}

II corpus dei disegni contiene II tavole di grande formato, dal 70,5 cm. per 68,2 cm dell'inquadramento topografico fino agli $81,0 \mathrm{~cm}$. per $187,6 \mathrm{~cm}$. del prospetto principale. Sono presenti: una planimetria in scala I: 1000; quattro piante ai vari livelli, inchiostrate su cartoncino, in scala I:200 (fig. I); tre piante, della Camera, del Senato e della Sala per le Sedute reali,

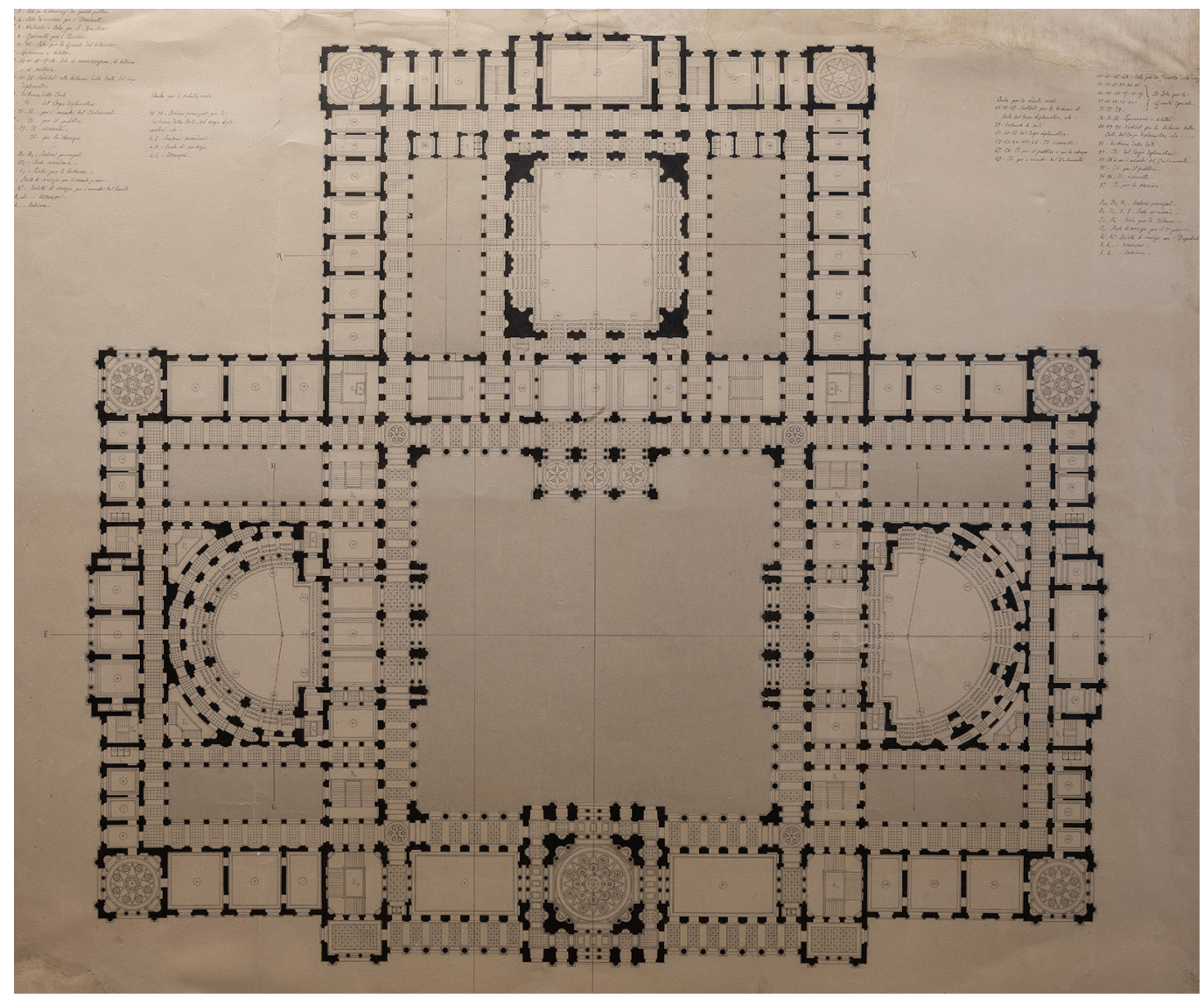


inchiostrate su cartoncino, in scala I: I00; il prospetto principale, ad inchiostro ed acquerello in scala I: I00; II prospetto posteriore e la sezione trasversale, a matita ed inchiostro su cartoncino, in scala I:200; i prospetti laterali, a matita, inchiostro ed acquerello su cartoncino, in scala I:200 [Mauro, Sessa, 2000a pp. I I I - I | 6; Mauro, Sessa 20 I 5, p. I43, p. 267].

L'edificio presenta uno schema rigoroso sviluppato intorno ad un grande cortile centrale, su cui affacciano il fronte della Camera dei Deputati, quello dell'Aula del Senato, entrambe emicicliche, e quello delle Sedute Reali, di forma rettangolare. La composizione è fortemente simmetrica e la presenza delle aule è evidenziata sui fronti da aggetti ben visibili. Il fronte principale ha una forte valenza monumentale, sottolineata dalla grande torre sovrastante l'ingresso, da due ali colonnate chiuse da torrini aggettanti e da due ali finestrate contigue chiuse dai torrini angolari.

II linguaggio, che mescola matrici neoromane, neoellenistiche e neorinascimentali [2], è caratterizzato da un basamento bugnato, da finestre a timpano e da colonne giganti corinzie sulle ali contigue all'ingresso, da semicolonne corinzie nei torrini angolari, colonne ioniche nelle finestre termali nei torrini, colonnine corinzie nei colonnati sommitali della torre d'ingresso, e paraste ioniche su tutti gli elementi secondari [3].

Nel I 890 Ernesto Basile pubblica il Progetto per il Palazzo del Parlamento Italiano premiato nel concorso nazionale del 1889 in cui sono riportati i disegni delle piante del Piano terreno e del Primo piano (Tav. I), del Prospetto principale sulla via Nazionale (Tav. II), la Sezione -E-F e la Sezione -A-B (Tav. III), il Prospetto laterale e il dettaglio di un Capitello dell'ordine principale - Al qvarto (Tav. IV) [Basile, I 890, pp. 4-7] [4] (fig. 2).

Per l'elaborazione del modello in esame si è fatto riferimento agli elaborati della pubblicazione sopra menzionata, in quanto sono una riproduzione dei disegni della versione definitiva. Pur essendo di dimensione ridotta [5], il confronto con gli originali della versione precedente, in scala I:I00 e 1:200, ha dimostrato che le dimensioni di lunghezza ed altezza, quelle degli interpiani, delle modanature e degli interassi sono state rispettate, pertanto le misure del modello digitale sono state desunte dai disegni in scala I//00 e 1:200.

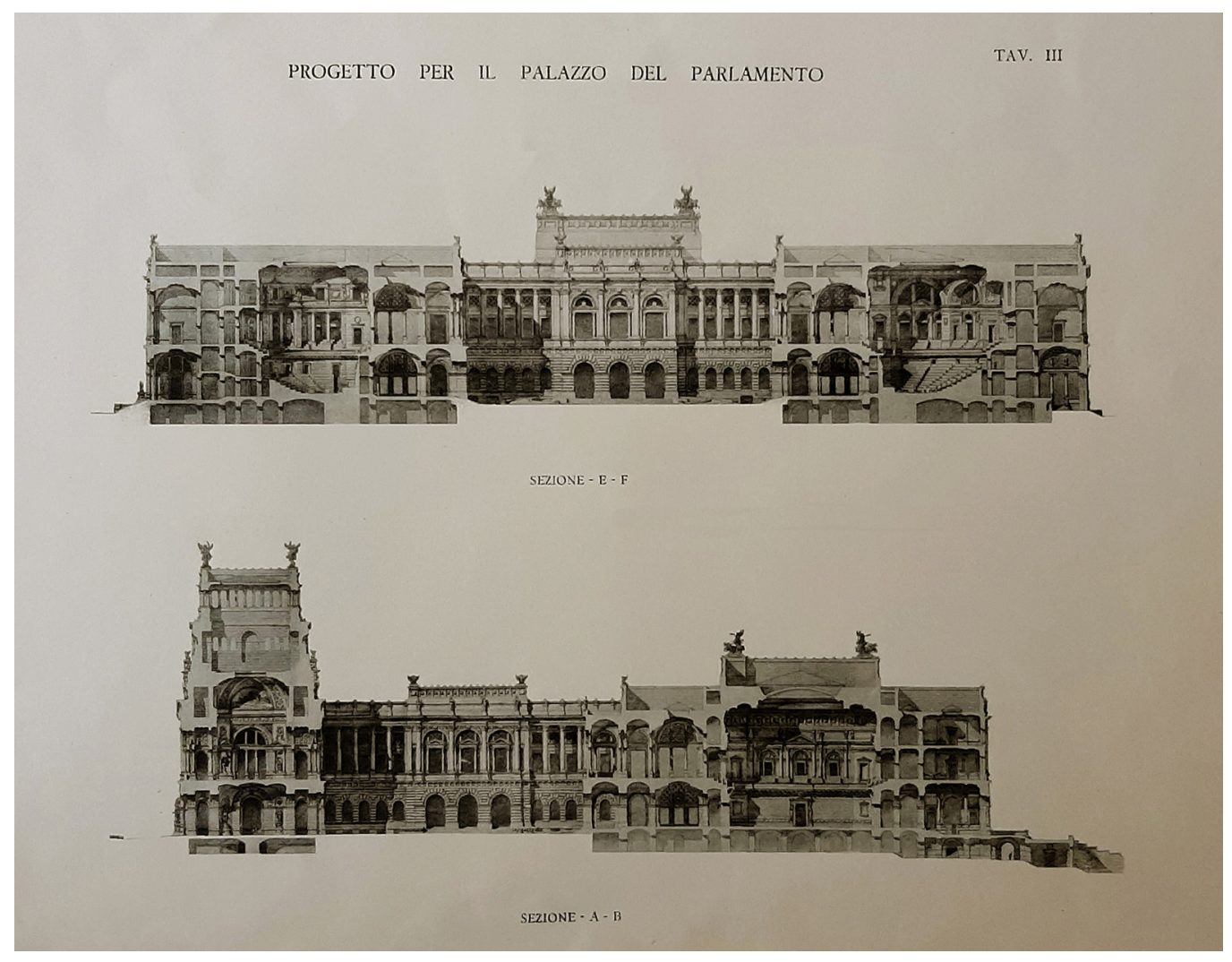


Fig. 3. Confronto tra il prospetto principale della prima variante, in scala 1:100, (matita, china, inchiostro ed acquerello su cartoncino, $810 \times 1876$ $\mathrm{mm}$.), redatto nel 1888 quello pubblicato in Basile E Progetto per il polozzo del parlamento italiano el pancorso nozional 889. Roma, 18

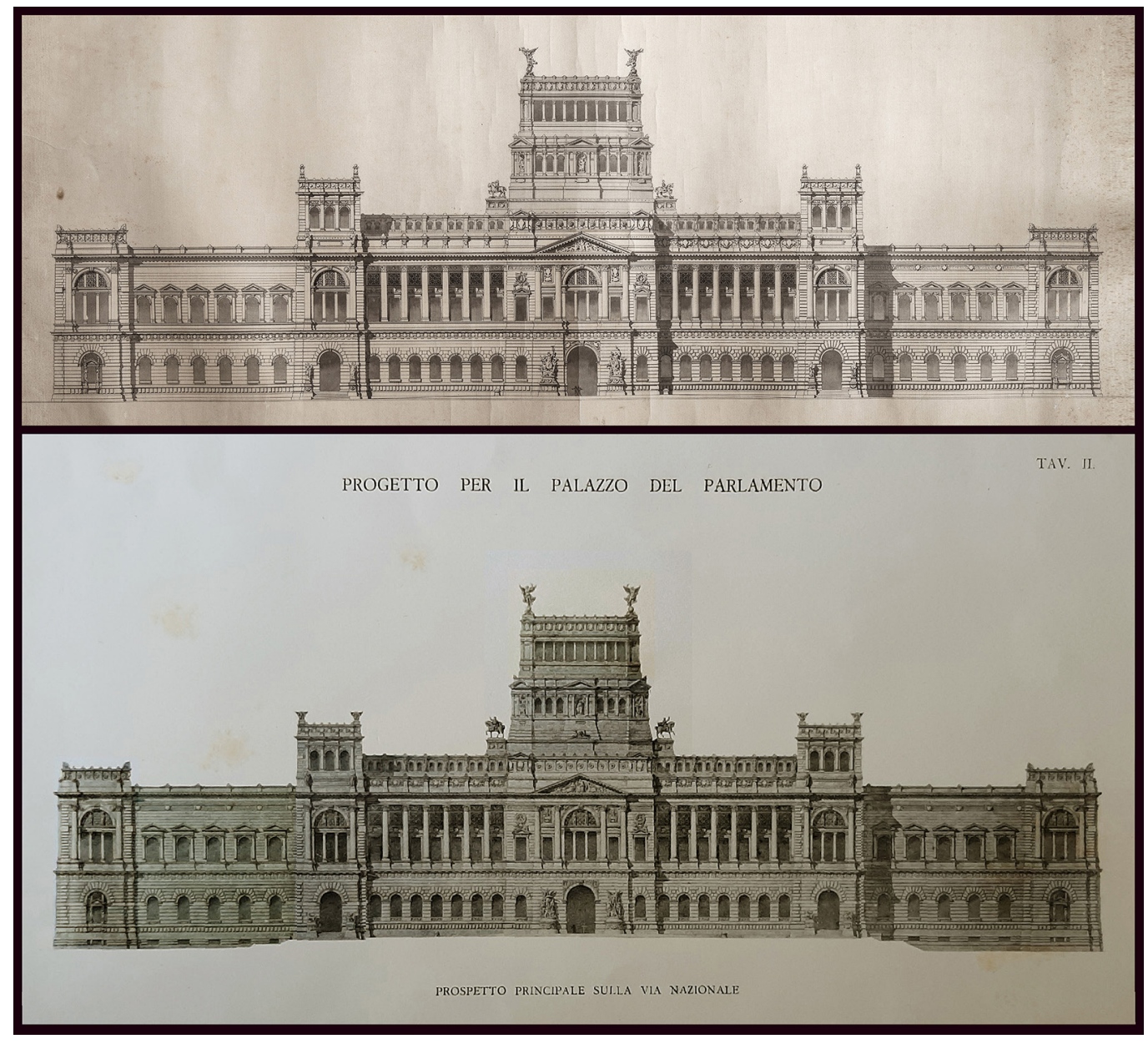

Si notano alcune differenze tra le due versioni: in particolare, il numero di aperture marcate da timpani triangolari ( 6 nella versione iniziale, 5 in quella definitiva) è congruente con quello delle piante, sono presenti aperture rettangolari nel basamento non indicate nel prospetto preparatorio, cambia il numero delle piccole paraste ioniche del muro d'attico dei torrini angolari, varia il numero dei conci bugnati nelle ghiere delle finestre di primo piano. Un'altra differenza è relativa alla cornice del piano terra: nel primo prospetto i triglifi sono in corrispondenza delle chiavi degli archi delle aperture, mentre nel secondo vi è uno sfalsamento che determina l'allineamento assiale delle metope. Un'ultima differenza riguarda la grande

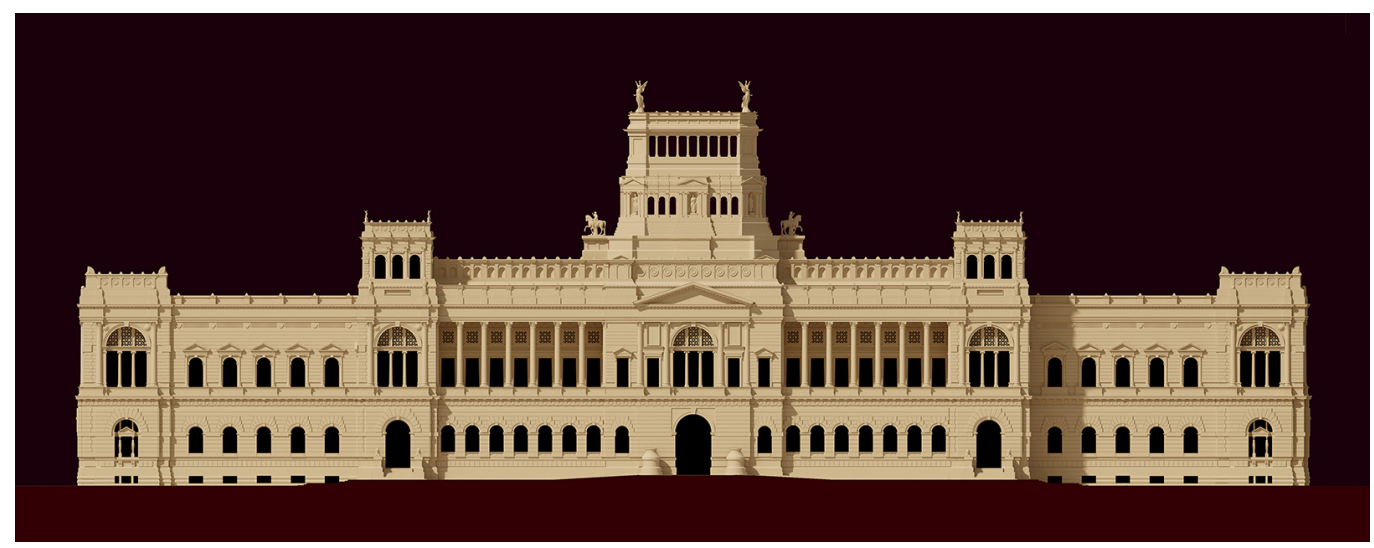


apertura ad arco dell'ingresso principale, leggermente incassata nel prospetto preparatorio, complanare in quello definitivo è (figg. 3-5).

Per costruire il modello si è partiti dalla verifica della congruenza tra i disegni vettoriali bidimensionali e i disegni originari, nonché dalla congruenza del modello tridimensionale con le informazioni vettoriali bidimensionali.

Un aspetto determinante è stato quello relativo alla finalità della modellazione: nel caso di modelli elaborati per analisi e viste renderizzate ci si può concedere alcune licenze: eventuali lacune, ad esempio, potrebbero non essere visibili e non mettono in discussione la resa finale.

II modello CAD propedeutico alla stampa 3D deve avere, invece, caratteristiche precise: già in fase di modellazione NURBS [6], infatti si devono evitare lacune, in modo da garantire la trasformazione in superfici poligonali perfettamente 'impermeabili', prive di discontinuità.

Un altro aspetto è stato quello relativo al livello di dettaglio. La mole dell'edificio è tale che le viste prospettiche d'insieme non consentono di apprezzare alcuni dettagli: pertanto, i modelli finalizzati alla renderizzazione avevano, volutamente, ridotto i livelli di dettaglio per evitare di avere un numero inutilmente elevato di poligoni, che, pur aumentando a dismisura i tempi di calcolo garantisce necessariamente innalzamento qualitativo.

Nel caso del modello propedeutico alla stampa 3D si è scelto, invece, di rendere uniforme il livello di dettaglio e renderlo compatibile con la scala di realizzazione di l:100.

In questa fase la realizzazione del modello in PLA è circoscritta a tutto il corpo del fronte principale, compreso il fronte interno prospicente il grande cortile, e sezionato in corrispondenza della mezzeria delle piccole corti rettangolari adiacenti alle Aule della Camera e del Senato.

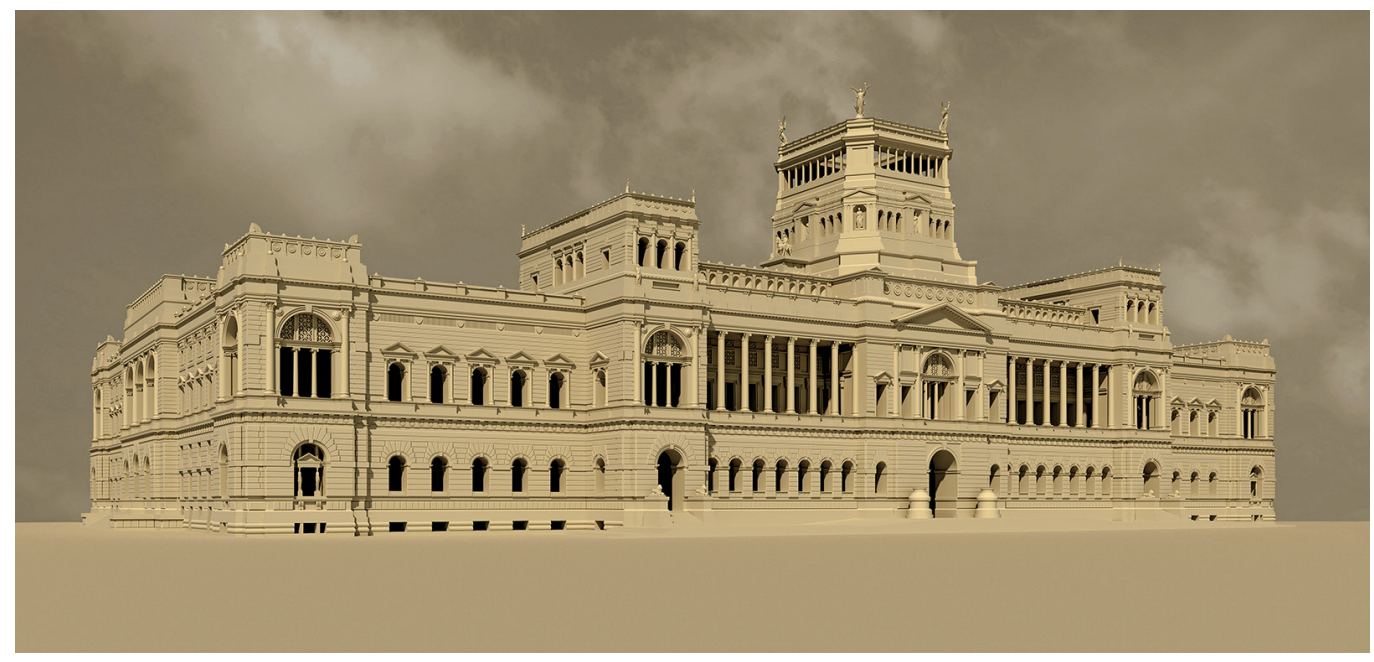

\section{Criteri di scomposizione del modello}

La realizzazione del modello in PLA ha comportato la progettazione di un sistema di scomposizione del modello digitale in elementi compatibili dimensionalmente con il volume stampabile.

La stampante utilizzata, di tipo cartesiano [7], ha un piatto di stampa di $22 \mathrm{~cm}$. $\times 22 \mathrm{~cm}$. ed un'altezza di volume stampabile di $25 \mathrm{~cm}$., dimensioni ovviamente incompatibili con quelle del modello che misura $187 \mathrm{~cm} \times 55 \mathrm{~cm} \times 45 \mathrm{~cm}$.

Si è stati costretti, pertanto, a scomporre il modello in elementi da assemblare dopo la stampa. Per evitare o, comunque, ridurre al minimo la presenza di fratture visibili si è deciso di identificare dei piani di giacitura orizzontali e verticali che consentissero di camuffare i piani di giunzione. 
II linguaggio classico dell'edificio è stato la fonte dello schema di scomposizione. Con riferimento al corpo principale ed ai torrini angolari i piani orizzontali sono stati posizionati in corrispondenza della sommità del basamento e del piano d'imposta delle architravi dell'ordine del primo piano, al fine di lasciare integri il fregio e la cornice; per la torre monumentale si scelto di posizionare i piani di sezione in corrispondenza del basamento che poggia sulla sommità dell'avancorpo centrale, sopra la cornice sovrastante i gruppi triforati ad arco e in corrispondenza dell'imposta dell'architrave dell'ultimo livello colonnato, isolando così la trabeazione ed il muro d'attico. Il posizionamento dei piani in corrispondenza delle architravi ha consentito, inoltre, di isolare le colonne corinzie dei due grandi loggiati delle ali laterali. I piani verticali sono stati posizionati in corrispondenza degli aggetti dei torrini angolari e della torre centrale, mentre, purtroppo, non è stato possibile evitare le giunzioni in mezzeria sulle ali fenestrate.

Su molti pezzi si è provveduto ad alloggiare dei piccoli elementi di giunzione "maschio e femmina" per prevedere un irrigidimento in fase di incastro (figg. 6, 7).

Si è provveduto, dunque, a stilare un abaco degli elementi in cui sono identificati i singoli pezzi (identificandone 47) ed il numero di repliche necessarie a riprodurre i corrispondenti seriali o simmetrici (da 2 a 8), per un totale complessivo di I 46 pezzi (fig. 8).
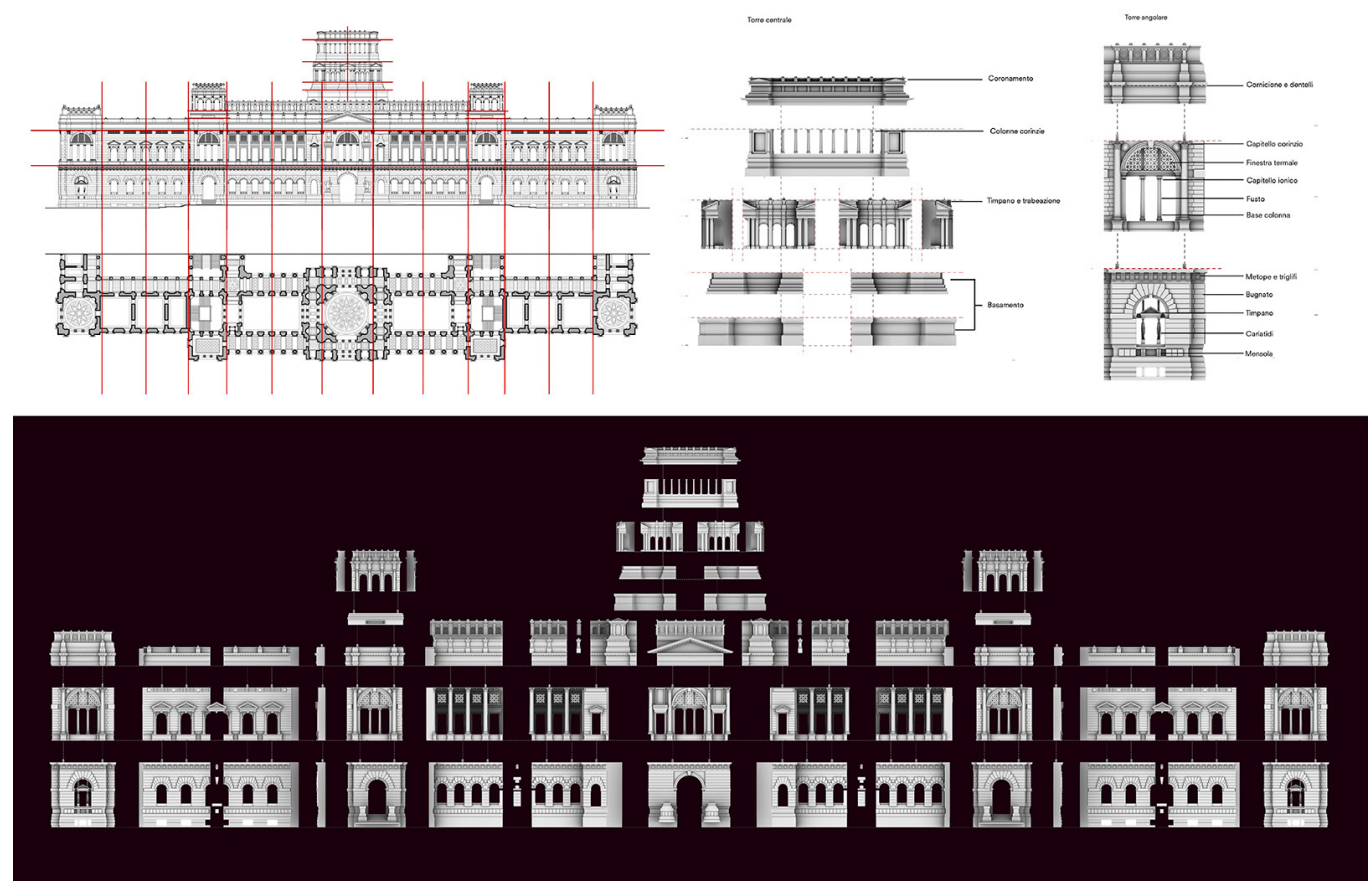

\section{Ottimizzazione, orientamento e slicing}

II modello CAD è stato successivamente importato in un software di slicing [8] per ottimizzarlo ed impostare i parametri di stampa.

La prima fase ha riguardato la correzione di lacune e sovrapposizioni per rendere la superficie poligonale perfettamente continua e priva di elementi intersecanti [9], per poi passare alla fase di orientamento e slicing [ 10$]$. Si è preferito orientare i pezzi posizionandoli in modo che la superficie muraria fosse parallela al piano di stampa, al fine di evitare il più possibile la visibilità dei layer e limitare al massimo l'utilizzo di supporti.

L'altezza dei layer di stampa è stata impostata su $0.28 \mathrm{~mm}$., ritenuto un buon compromesso tra qualità di stampa e tempi di realizzazione. In alcuni casi si è dovuto ridurre il valore a 0.24 per consentire la realizzazione di alcuni elementi ad alto livello di dettaglio, come nel caso del fregio del piano basamentale, in cui lo spessore di $0.28 \mathrm{~mm}$. non consentiva 


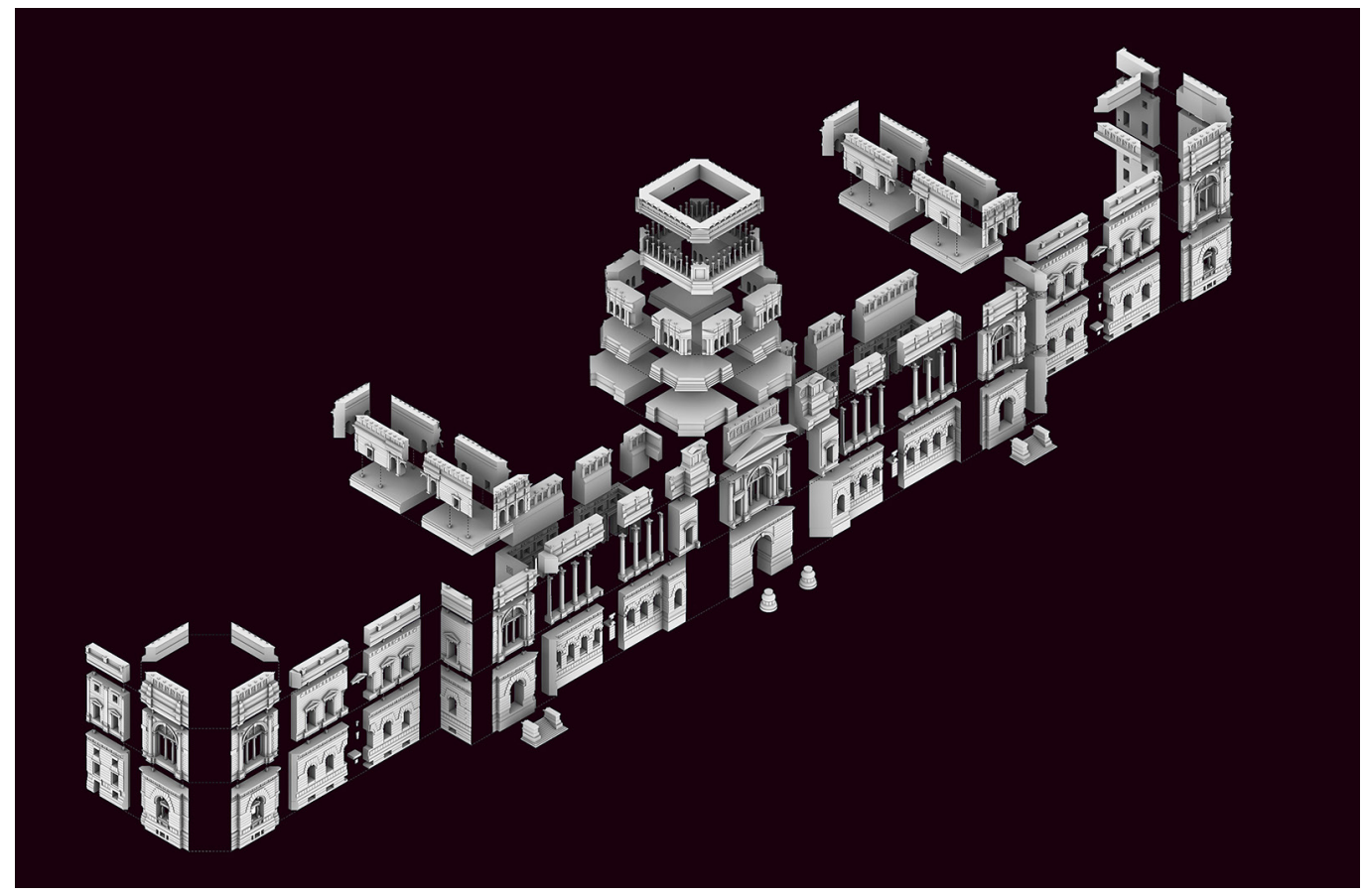

la definizione di triglifi e metope. Per la stampa di elementi scultorei l'altezza si è ridotta ulteriormente a $0.12 \mathrm{~mm}$.

L'utilizzo di questi parametri ha permesso di ottimizzare i tempi di stampa garantendo un buon livello qualitativo, limitando la scelta di parametri particolarmente elevati solo nel caso in cui si voleva salvaguardare la resa di elementi architettonici e decorativi di particolare pregio e necessari a rappresentare il linguaggio classico dell'edificio.

Ogni pezzo è stato suddiviso in 2 strati inferiori e 4 superiori, al fine di garantire una migliore finitura dello strato visibile. Lo strato intermedio presenta un riempimento con una griglia

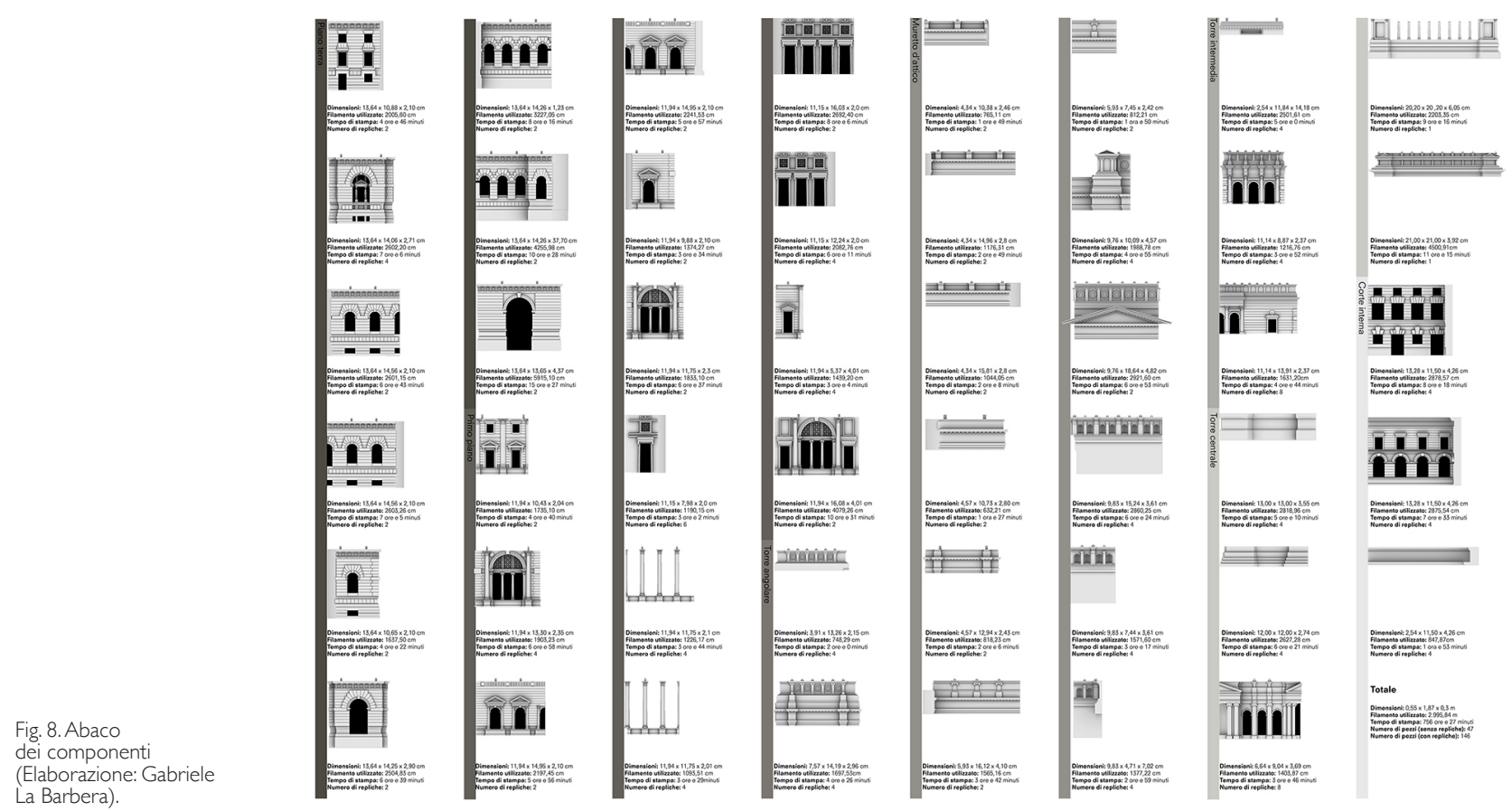


a maglia quadrata inclinata a $45^{\circ}$, con una densità dell' $8 \%$, sufficiente a garantire la rigidità dei pezzi con una quantità di materiale utilizzato non eccessiva e una riduzione dei tempi di stampa [I l] (fig. 9).

\section{Post-produzione, assemblaggio e finitura}

La fase successiva è stata la post-produzione della stampa 3D. I pezzi sono stati sottoposti all'eliminazione dello strato di adesione al piatto di stampa, nel caso in esame generato in modalità brim [12], e dei supporti, laddove necessari.

I pezzi hanno ricevuto una prima levigatura superficiale, una verifica dell'assemblaggio e l'incollaggio con colla acrilica a base d'acqua, capace di garantire la tenuta sino a $60 \mathrm{~kg} / \mathrm{cm}^{2}$. Man mano che si è proceduto all'incollaggio si è effettuata la stuccatura, sia per regolarizzare alcune microlacune dovute al ritiro del PLA, sia per riempire i pochi giunti visibili, ed una seconda levigatura.

La fase finale è stata quella della verniciatura su primer, necessaria a rendere omogeneo il modello per coprire le diverse tonalità di bianco dei filamenti e le porzioni stuccate. Si è scelto un bianco perlato, ad acrilico, passato con aerografo, per ottenere superficie neutra, vista la mancanza di informazioni materiche, sia nei disegni, sia nelle memorie (figg. I0- I2).
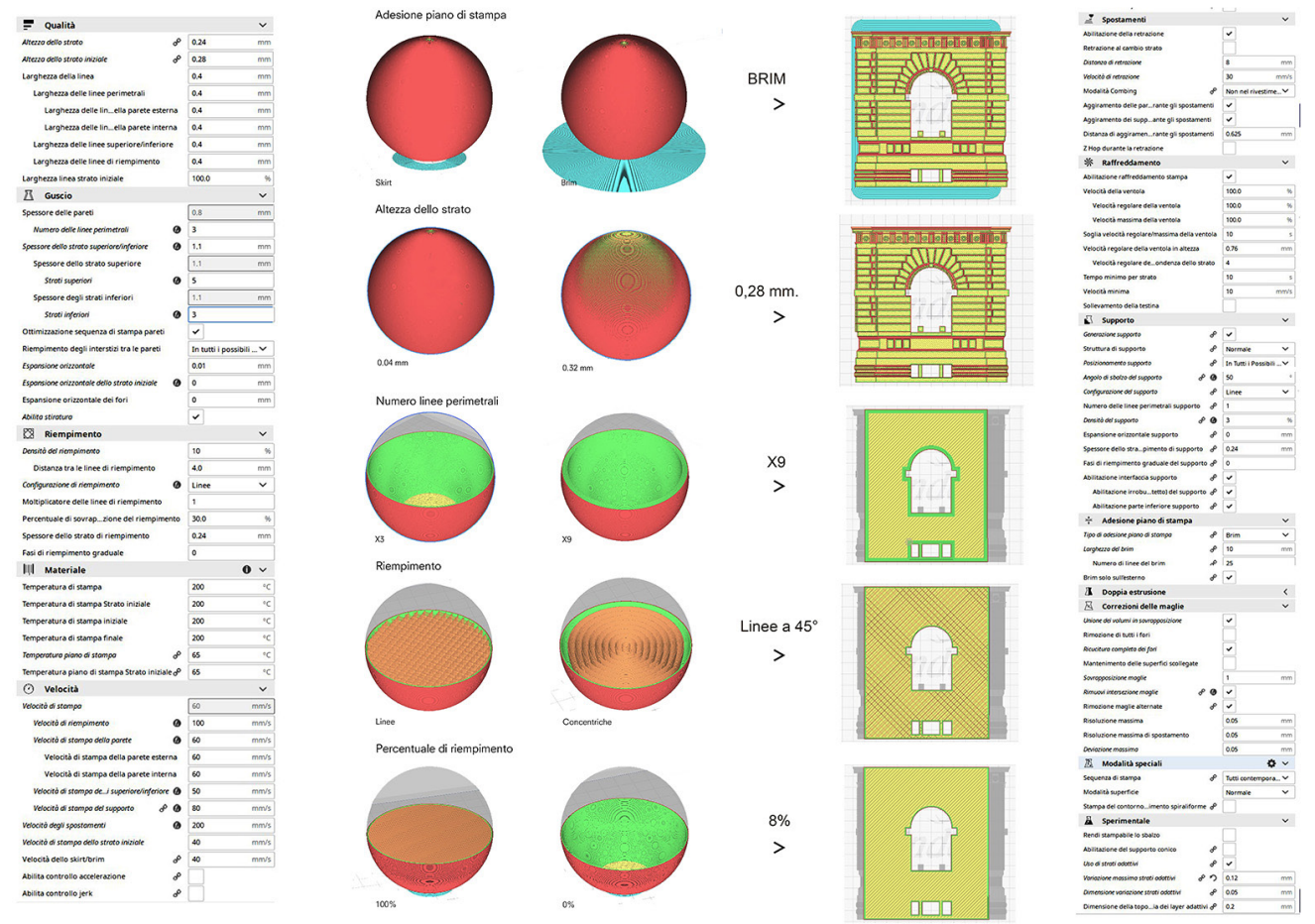

\section{Conclusioni}

Il presente lavoro costituisce un ulteriore elemento di conoscenza di questo progetto dal grande valore storico e offre la possibilità di vedere la tridimensionalità della facciata, coglierne la qualità architettonica ed apprezzarne il linguaggio classico.

II modello sarà visibile in esposizione permanente presso la Dotazione Basile del Dipartimento di Architettura dell'Università di Palermo e sarà inserito nel fondo Miscellanea del Dipartimento di Architettura di Palermo. 
Fig. 10. Modello in PLA, vista d'insieme (Elaborazione: Gabriele La Barbera).

Fig. I I. Modello in PLA ingresso monumentale
(Elaborazione: Gabriele La Barbera).
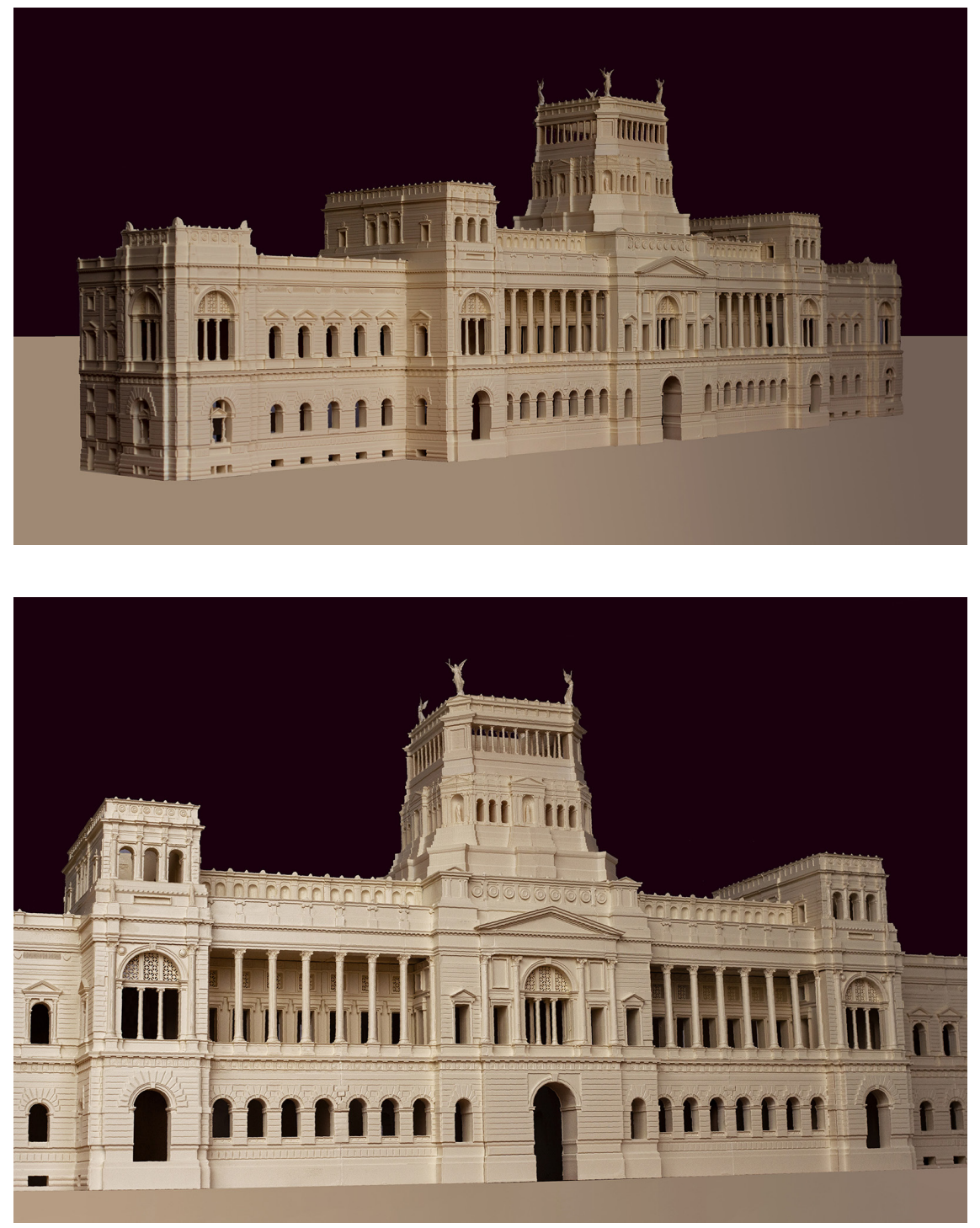

Fig. 12. Modello in PLA dettaglio della torre

angolare (Elaborazione: Gabriele La Barbera).

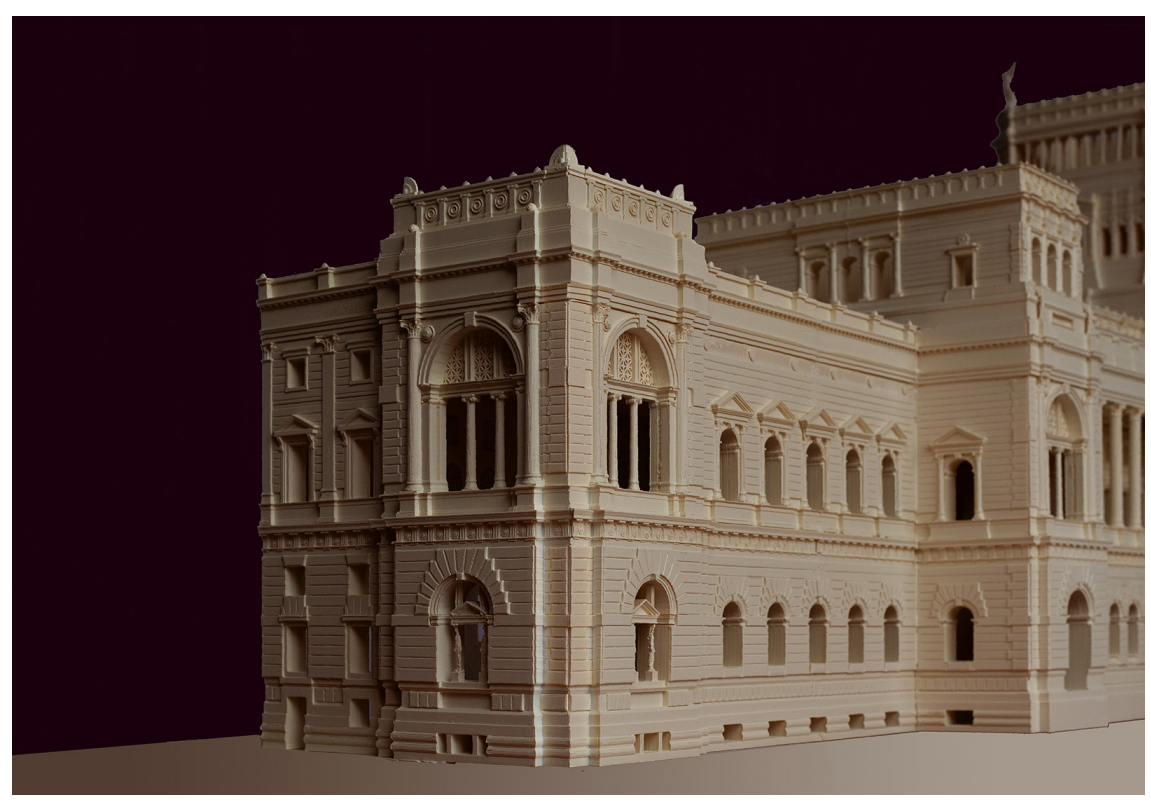




\section{Note}

[I] Gli altri progettisti premiati sono Gaetano Moretti, Luigi Broggi e Giuseppe Sommaruga, Pier Paolo Quaglia Vincenzo Benvenuti, Enrico Ristori [Sessa, 2002, p. 58].

[2] Sul linguaggio architettonico dell'edificio cfr. Sessa, 2002, pp. 58-62.

[3] Sul linguaggio architettonico di Ernesto Basile cfr. Sessa, 2002. Per una descrizione del progetto in esame cfr. Mauro, Sessa (a cura di), 2000b, pp. 34-42.

[4] Presso la Dotazione Basile del Dipartimento di Architettura vi sono tre copie, raccolte in un fascicolo (Coll. Basile 42 [6]/2).

[5] Le tavole sono di formato $30 \mathrm{~cm} \times 38 \mathrm{~cm}$ che comporta una riduzione dei disegni in scala I/692.

[6] II modello NURBS è stato realizzato con Rhinoceros.

[7] II software utilizzato è Creality Ender 3 Pro.

[8] II software utilizzato è Ultimaker Cura.

[9] La funzione utilizzata è Ricucitura completa dei fori ed Unione dei volumi in sovrapposizione.

[I0] Per slicing si intende la generazione di un G-Code che gestisce le informazioni sui parametri necessari all'ottimizzazione del processo di stampa.

[ I I ] Sul workflow del processo di modellazione, settaggio e stampa 3D cfr. Bañón, Raspall 2020.

[12] Questa modalità assicura migliora planarità e adesione al piatto di stampa, ed una facile rimozione del pezzo dai contorni.

\section{Riferimenti bibliografici}

Avella F. (2020). II secondo concorso per il Parlamento di Ernesto Basile. Analisi e ricostruzione congetturale. In Arena A. et al. (a cura di). Connettere. Un disegno per annodare e tessere. Atti del $42^{\circ}$ Convegno Internazionale dei Docenti delle Discipline della Rappresentazione/Connecting. Drawing for weaving relationships. Proceedings of the 42th International Conference of Representation Disciplines Teachers, pp. I622- I 643. Milano: Franco Angeli.

Bañón C, Raspall F. (2020). 3D Printing Architecture. Workflows, applications, and trends. Singapore: Springer.

Basile E. ( 1890). Progetto per il palazzo del parlamento italiano nel concorso nazionale del I 889. Roma: Stabilimento Tipografico. Italiano.

Mauro E., Sessa E. (a cura di). (2000a). Giovan Battista Filippo Basile ed Ernesto Basile: settant'anni di Architetture: $i$ disegni restaurati della Dotazione Basile, 1859-1929. Palermo: Novecento.

Mauro E., Sessa E. (a cura di). (2000b). Ernesto Basile a Montecitorio e i disegni restaurati della Dotazione Basile. Palermo: Novecento.

Mauro E., Sessa E. (20 I 5). I disegni della Collezione Basile. Roma: Officina Edizioni.

Sessa E. (2002). Ernesto Basile. Dall'eclettismo classicista al modernismo. Palermo: Novecento.

\section{Autore}

Fabrizio Avella, Università degli Studi di Palermo, fabrizio.avella@unipa.it

Per citare questo capitolo: Avella Fabrizio (202I). II secondo concorso per il Parlamento di Ernesto Basile. Criteri di modellazione e stampa 3D/ The Second Competition for the Parliament Building in Rome by Ernesto Basile. 3D Modelling and Printing Criteria. In Arena A. Arena M. Mediati D. Raffa P. (a cura di). Connettere. Un disegno per annodare e tessere. Lingugogi Distanze Tecnologie. Atti del $42^{\circ}$ Convegno Internazionale 42th International Conference of Representation Disciplines Teachers. Milano: FrancoAngeli, pp. 1978-1997. 


\section{The Second Competition for the Parliament Building in Rome by Ernesto Basile. 3D Modelling and Printing Criteria}

Fabrizio Avella

Abstract

The project for the second competition for the Parliament by Ernesto Basile, awarded in 1890, is configured as a work of great value in the production of the architect of Palermo and as a precious testimony to the history of architecture and the history of design.

The original drawings, kept at the Basile Endowment of the Department of Architecture of the University of Palermo, already subject of study and analysis, were used for further processing aimed at creating a 3D printed model in I: 100 scale, which will be on permanent display at the Endowment itself. This study describes the methodological process, the implementation criteria and the results achieved.

Keywords

Ernesto Basile, digital modelling, 3d printing.

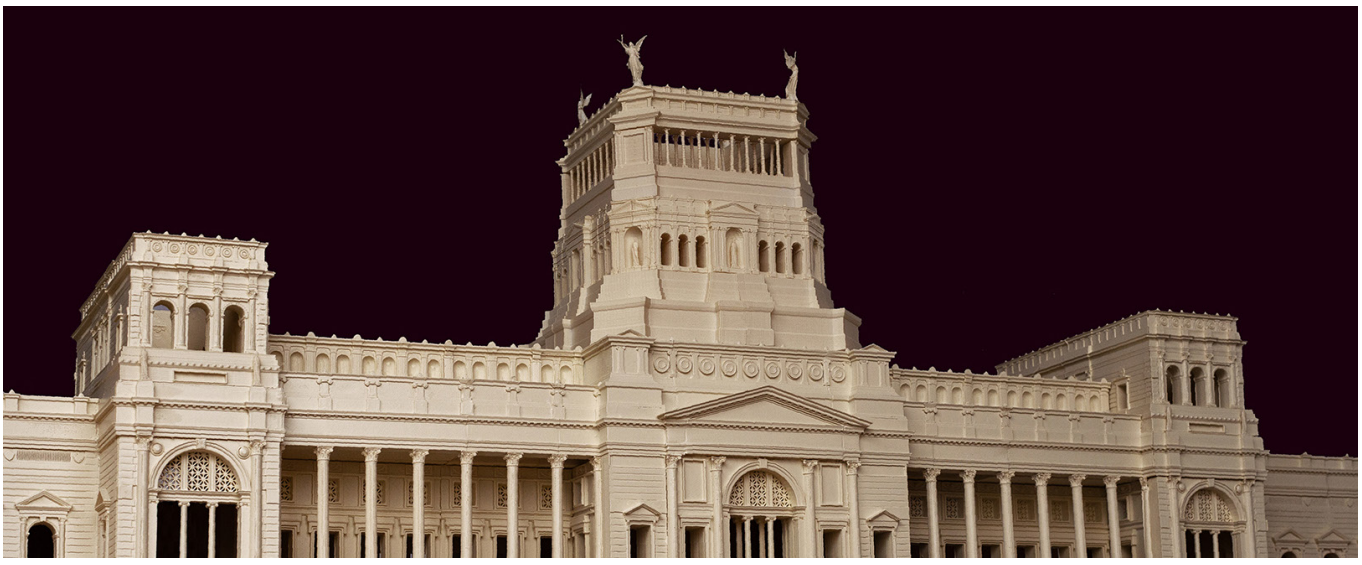




\section{Introduction}

The project for the second competition for the Parliament of the Kingdom of Italy, drawn up between I 888 and I889, sees as the winner ex aequo [I] the young Ernesto Basile (Palermo 1857- 1932), who had already participated in the competition for the Palazzo di Giustizia in Rome, held between 1884 and I887, which was won by Guglielmo Calderini.

The project will not be carried out, due to the fall of the Crispi government in I89|, but Basile will be called to develop the project for the extension of the Montecitorio building between 1903 and 1918, realizing the project for the building containing the Chamber dei Deputati, still existing today, to be considered "a sort of budding, from the organism of its second Parliament Building" [Mauro, Sessa, 2000b, p. 4I].

The drawings are preserved in the Basile Endowment of the Scientific Collections of the Department of Architecture of the University of Palermo, of which Professor Ettore Sessa is the Scientific Responsible.

A first conjectural reconstruction study of the work has already been published and we refer to that text for the criteria of interpretation, vectorization, modelling and graphic analysis [Avella 2020, pp. I622-1643].

Here we report the steps of the process necessary for the remodelling of the three-dimensional model and the optimization necessary for the creation of a 1:I00 scale PLA model.

\section{Analysis of sources and modelling criteria}

The corpus of drawings contains I I large format plates, from $70.5 \mathrm{~cm}$. for $68.2 \mathrm{~cm}$ of the topographical framework up to $81.0 \mathrm{~cm}$. for $187.6 \mathrm{~cm}$. of the main elevation. There are: a I: 1000 scale plan; four plants at various levels, inked on cardboard, on a scale of $1: 200$

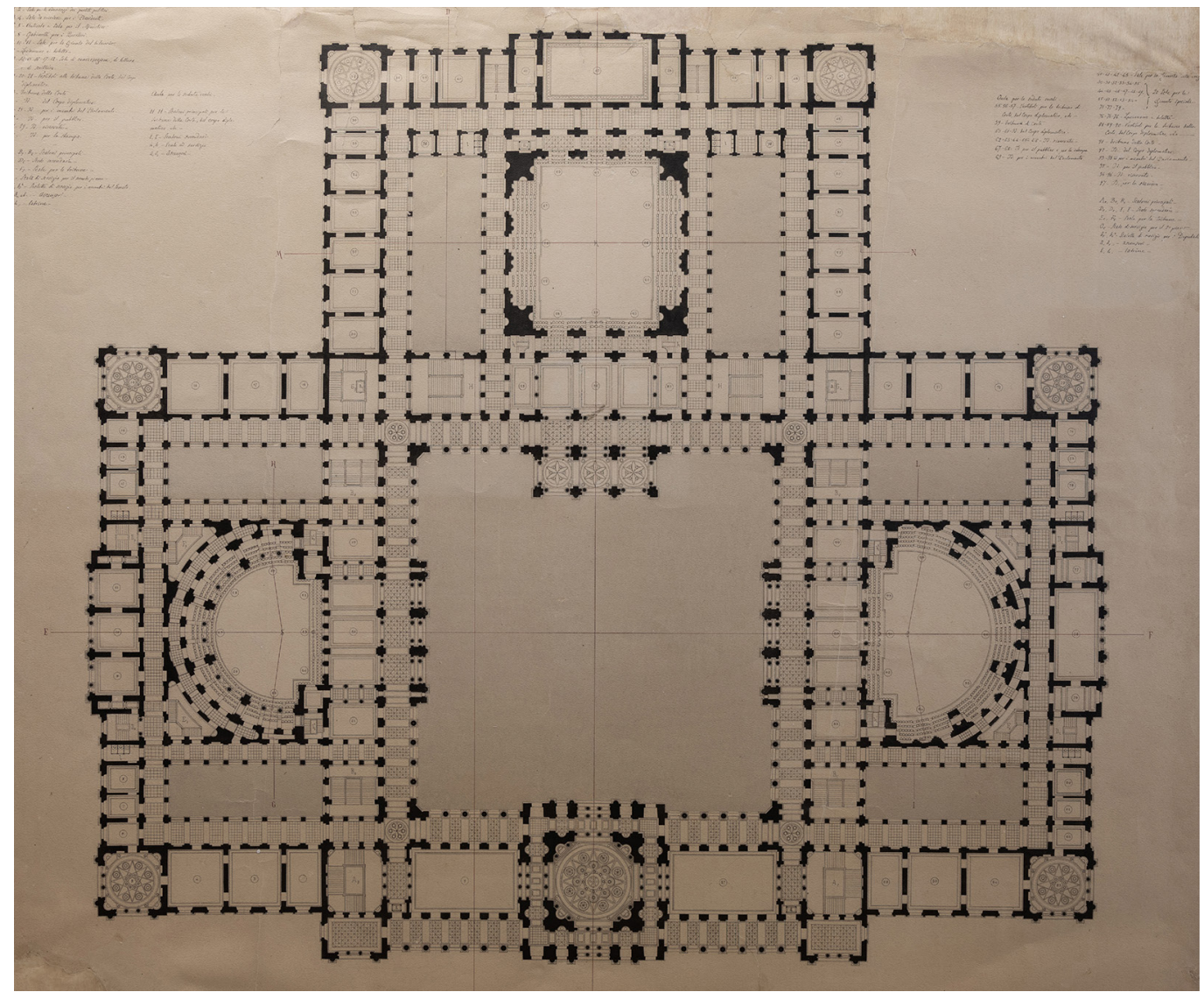


(fig. I); three plans, of the Chamber, the Senate and the Hall for Royal Sessions, inked on cardboard, in scale I: 100; the main façade, in ink and watercolour on a scale of I: I00; The rear elevation and the cross section, in pencil and ink on cardboard, at a scale of $1: 200$ (fig. I); the side elevations, in pencil, ink and watercolour on cardboard, on a scale of $1: 200$ [Mauro, Sessa, 2000a, pp. I I | - I 6; Mauro, Sessa, 20 I5, p. 143, p. 267].

The building has a rigorous scheme developed around a large central courtyard, overlooked by the front of the Hall of Deputies, that of the Senate Hall, both hemicyclic, and that of the Royal Sessions, rectangular in shape. The composition is strongly symmetrical and the presence of the classrooms is highlighted on the fronts by clearly visible overhangs. The main façade has a very pronounced monumental value, underlined by the large tower at the main entrance, by two colonnaded wings closed by projecting towers and by two contiguous windowed wings closed by the corner towers, which act as closure and hinge of all fronts.

The language, which mixes Neo-Roman, Neo-Hellenistic and Neo-Renaissance matrices [2], is characterized by an ashlar base, gable windows and giant Corinthian columns on the adjacent wings at the entrance, Corinthian semi-columns in the corner towers, lonic columns in the thermal windows in the small towers, Corinthian columns in the top colonnades of the entrance tower, and lonic pilasters on all secondary elements [3].

In 1890 Ernesto Basile published the Project for the Italian Parliament Building which was awarded in the national competition of I 889, which shows the drawings of the Ground floor and First floor plans (Table I), of the Main elevation on via Nazionale (Table II), the Section -EF and the Section -AB (Table III), the Side elevation and the detail of a Capital of the main order - to the fourth (Table IV) ) [Basile, I890, pp. 4-7] [4] (fig. 2).

For the development of the model, reference was made to the documents of the aforementioned publication by Ernesto Basile, as they are a reproduction of the drawings of the final version. Although small in size [5], the comparison with the originals of the previous version, in 1:1 00 and I:200 scale, has shown that the overall dimensions of length and height, those of the inter-floors, mouldings and modular axes have been respected, therefore the measurements of the digital model were taken from the 1:100 and 1:200 scale drawings.

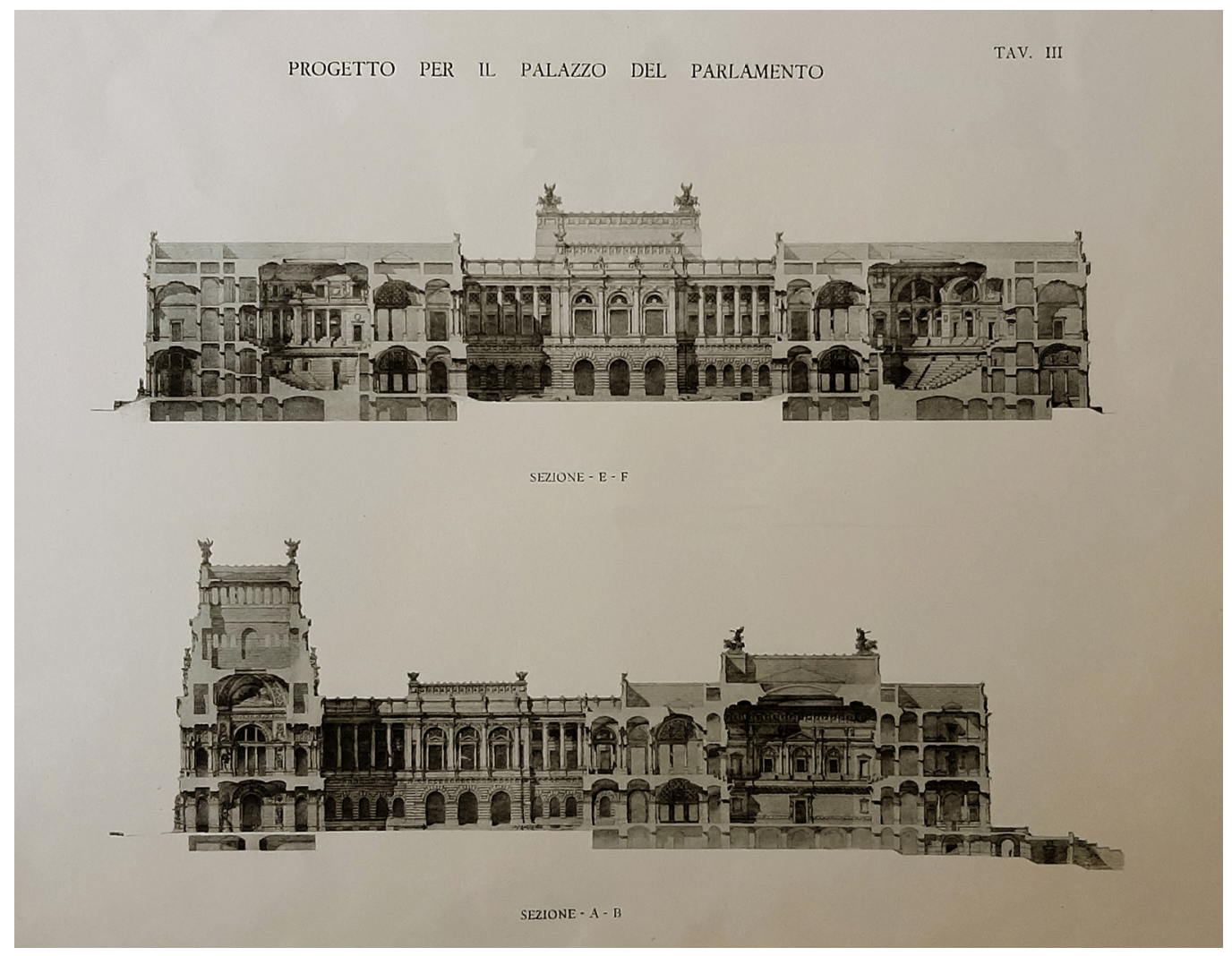


Fig. 3. Comparison between the main elevation of the first variant, in scale I: 100 (pencil, ink, ink and watercolor on cardboard, $810 \times 1876 \mathrm{~mm}$.), Drawn up in 1888 and the one published in E. Basile. Project for the palace of the Italian parliament in the national competition the 1889 . Rome, 1890 Plate

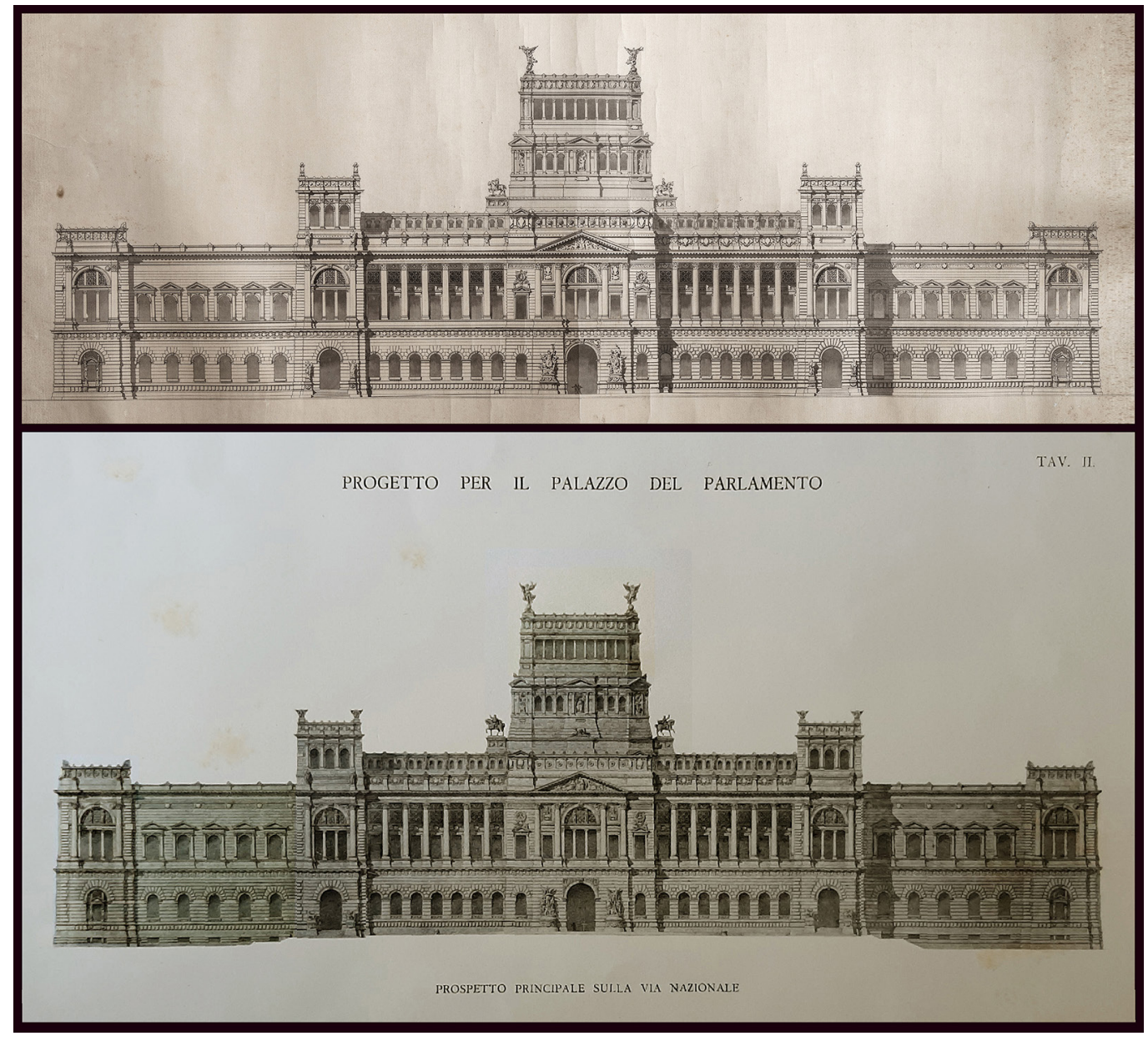

There are some differences between the two versions: in particular, the number of windows marked by triangular gables ( 6 in the initial version, 5 in the final one) is congruent with that present in the plans, there are small rectangular windows in the base not indicated in the prospectus preparatory, the number of small lonic pilasters present on the attic wall of the corner towers changes, the number of ashlar blocks in the rings of the foreground windows changes. Another difference relates to the ground floor frame: in the first elevation, the triglyphs are placed in correspondence with the keys of the arches of the openings, while in the second there is an offset that determines the axial alignment of the metopes. A final

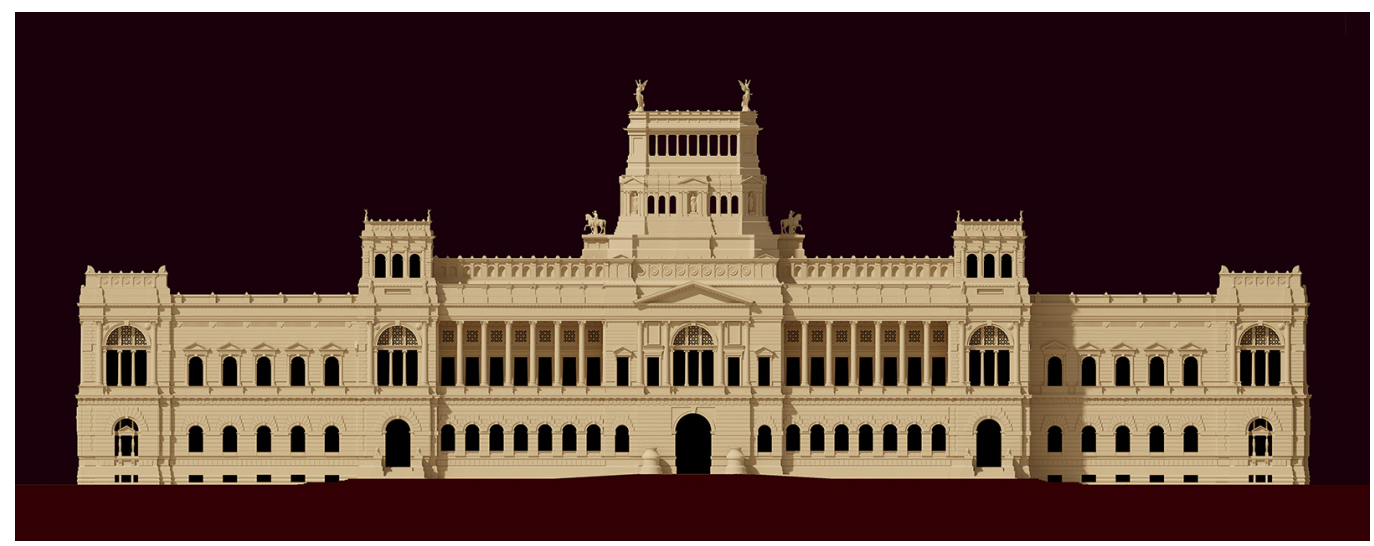


difference concerns the large arched opening of the main entrance which is slightly recessed in the preparatory façade, while in the final one it is coplanar (figs. 3-5).

To build the model we started by checking the congruence between the two-dimensional vector drawings and the original drawings, as well as the congruence of the three-dimensional model with the two-dimensional vector information.

A decisive aspect was that relating to the purpose of the modelling: in the case of models developed for analysis and rendered views, certain licenses can be granted: any gaps, for example, may not be visible and do not question the final yield.

The CAD model preparatory to $3 D$ printing must, on the other hand, have precise characteristics: already in the NURBS modelling phase [6], in fact, gaps must be avoided, in order to guarantee the transformation into perfectly "waterproof" polygonal surfaces, which do not have the slightest discontinuity.

Another aspect was related to the level of detail. The size of the building is such that the overall perspective views do not allow to appreciate some details: therefore, the models aimed at rendering had, deliberately, reduced the levels of detail to avoid an unnecessarily high number of polygons that would have dramatically increased the calculation times without this turning into a qualitative increase.

In the case of the preparatory model for 3D printing, instead, it was decided to make the level of detail uniform and make it compatible with the I: I 00 construction scale.

In this phase, the realization of the PLA model is limited to the entire body of the main front, including the internal front facing the large courtyard, and sectioned in correspondence with the small rectangular courtyards adjacent to the Halls of the Chamber and Senate.

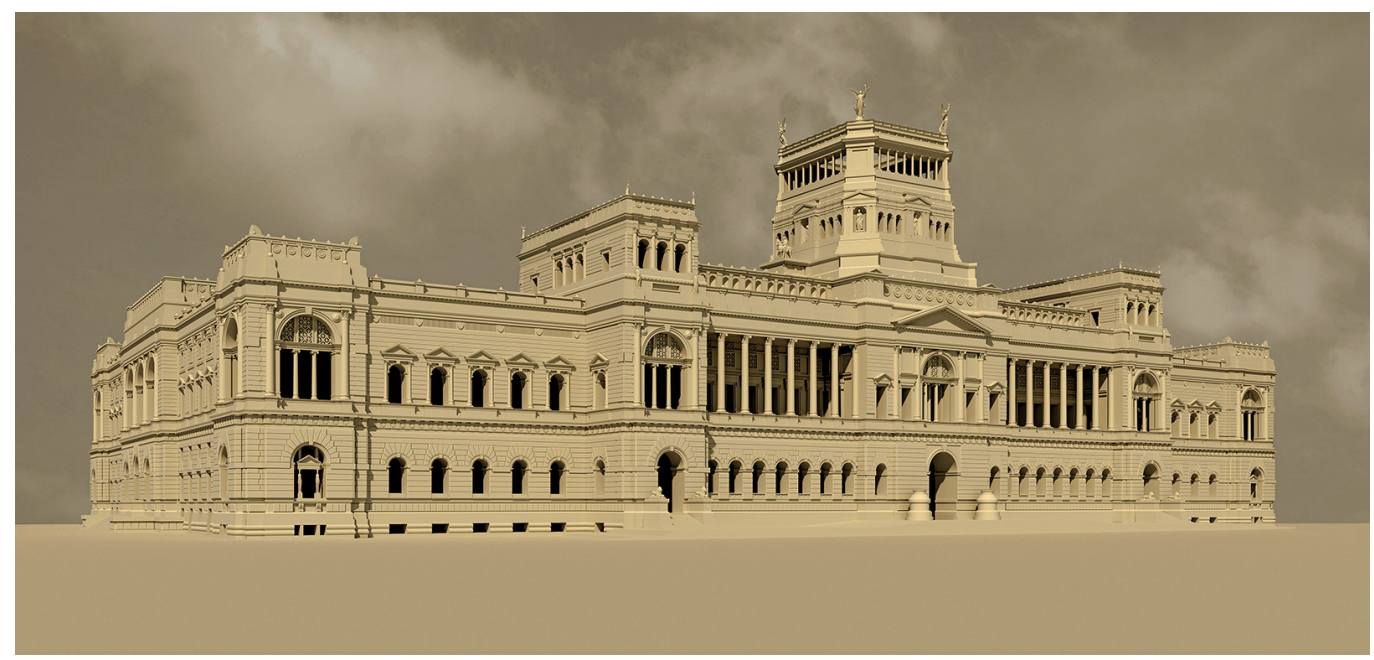

\section{Decomposition criteria of the model}

The realization of the model in PLA involved the design of a system for breaking down the digital model into elements that are dimensionally compatible with the printable volume. The printer used, of Cartesian type [7], has a printing plate of $22 \mathrm{~cm} . \times 22 \mathrm{~cm}$. and a printable volume height of $25 \mathrm{~cm}$., dimensions obviously incompatible with those of the model which measures $187 \mathrm{~cm} \times 55 \mathrm{~cm} \times 45 \mathrm{~cm}$.

We were therefore forced to break down the model into individually printable elements, to be assembled later.To avoid or, in any case, minimize the presence of visible fractures, it was decided to identify horizontal and vertical planes that would allow the junction planes to be camouflaged. The classical language of the building was the source of the decomposition scheme. With reference to the main body and the corner towers, the horizontal planes were positioned at the top of the base and the shutter plane of the architraves of the first floor order, in order 
to leave the frieze and the frame intact; for the monumental tower it was decided to position the section planes in correspondence with the base that rests on the top of the central forepart, above the cornice above the tri-perforated arched groups and in correspondence with the architrave of the last colonnaded level, isolating likewise the entablature and the attic wall. The positioning of the floors in correspondence with the architraves also made it possible to isolate the Corinthian columns of the two large arcades of the side wings.

The vertical planes were positioned in correspondence with the projections of the corner towers and the central tower, while, unfortunately, it was not possible to avoid the junctions in the middle of the fenestrated wings.

Small 'male and female' junction elements were placed on many pieces to provide stiffening during the interlocking phase (figs. 6-7).

An abacus was therefore drawn up of the elements in which the individual pieces are identified (identifying 47) and the number of replicas necessary to reproduce the corresponding serial or symmetrical (from 2 to 8), for a total of I 46 pieces (fig. 8).
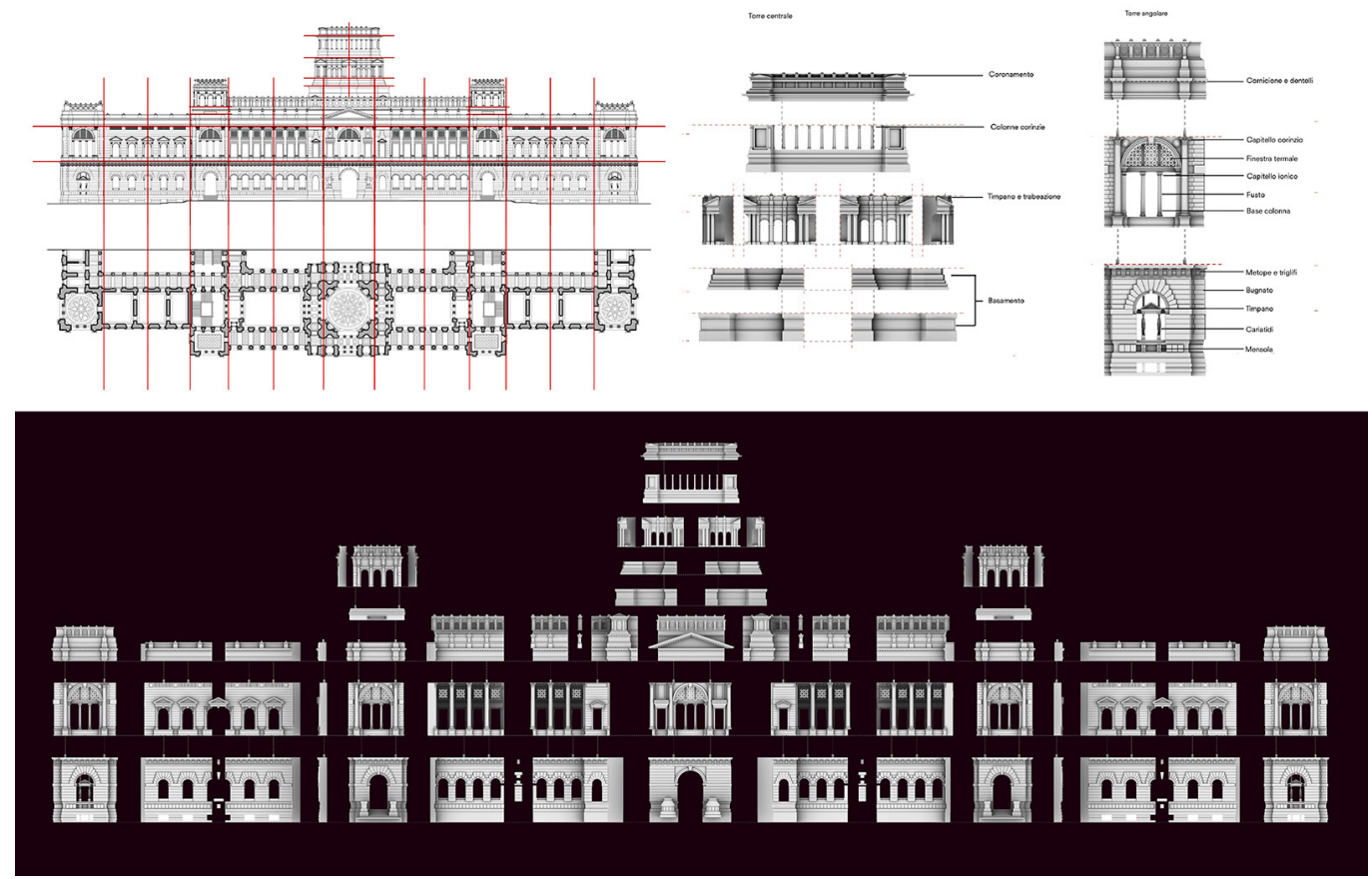

\section{Optimization, orientation and slicing}

The CAD model was subsequently imported into a slicing software [8] in which the model is optimized and the printing parameters are set.

The first phase concerned the correction of any gaps, often present even in very accurate CAD models, and overlapping to make the polygonal surface perfectly continuous and free of intersecting and self-intersecting elements [9].

For each single piece, we moved on to the orientation and slicing phase [ 10$]$. It was preferred to orient the pieces by positioning them so that the wall surface was parallel to the printing surface, in order to avoid as much as possible the visibility of the layers and to limit the use of supports as much as possible.

The height of the print layers was set to $0.28 \mathrm{~mm}$., considered a good compromise between print quality and production times. In some cases it was necessary to reduce the value to 0.24 to allow the creation of some elements with a good level of detail, as in the case of the frieze of the base plane, in which the thickness of $0.28 \mathrm{~mm}$. did not allow the definition of triglyphs and metopes. For the printing of sculptural elements, the height was further reduced to $0.12 \mathrm{~mm}$. 
Fig. 7. Axonometric exploded view of the model and the assembly of the components

((Elaboration: Gabriele La Barbera).

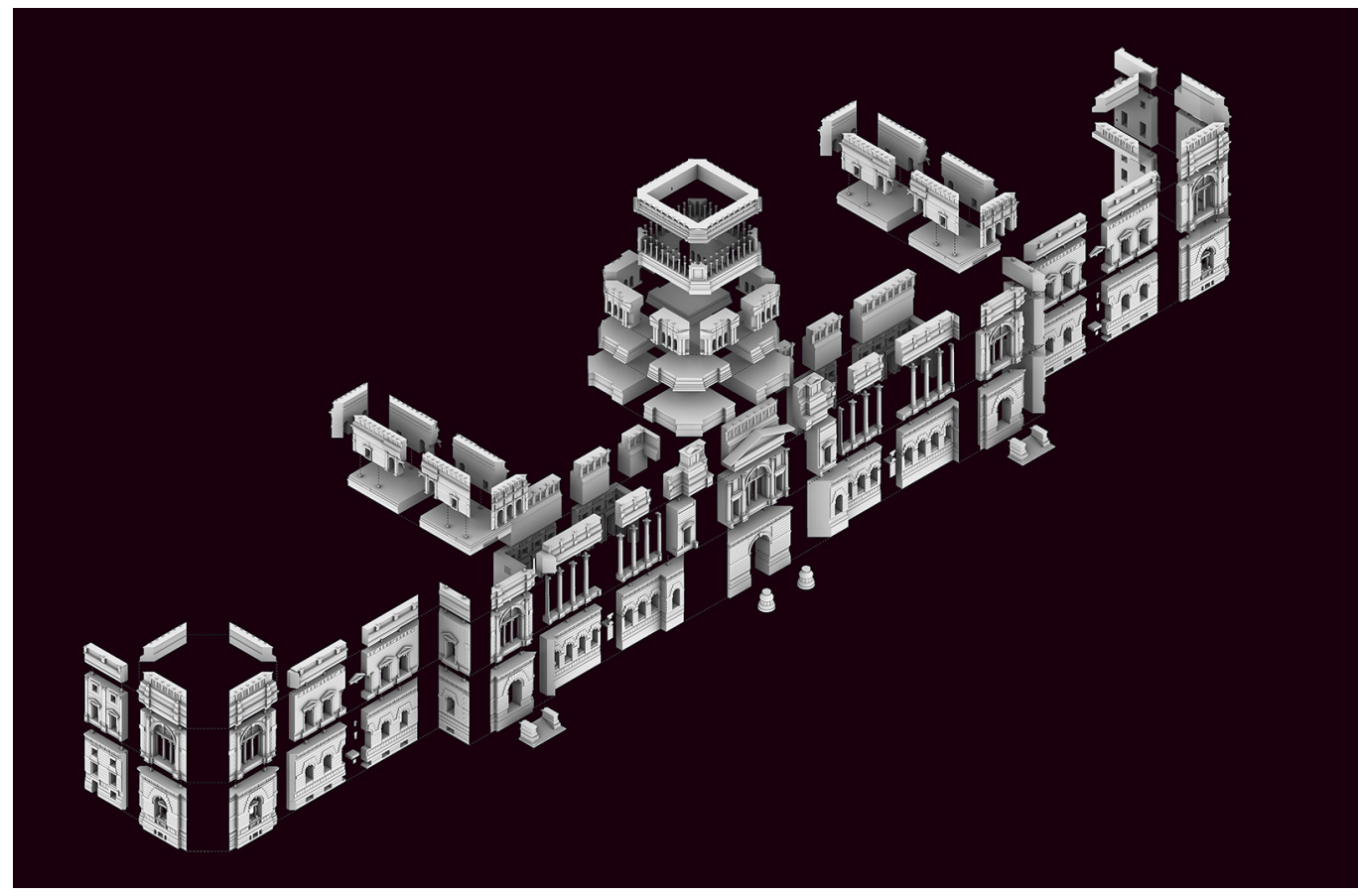

The use of these parameters has made it possible to optimize printing times, guaranteeing a good quality level, limiting the choice of particularly high parameters only in the case of a good rendering of architectural and decorative elements of particular value and necessary to represent the classical language of the building.

Each piece has been divided into 2 lower and 4 upper layers, in order to ensure a better finish of the visible layer.The intermediate layer has a filling with a square mesh grid inclined at $45^{\circ}$, with a density of $8 \%$, sufficient to guarantee the rigidity of the pieces with a not excessive amount of material used and a reduction in printing times [I I ] ( fig. 9).

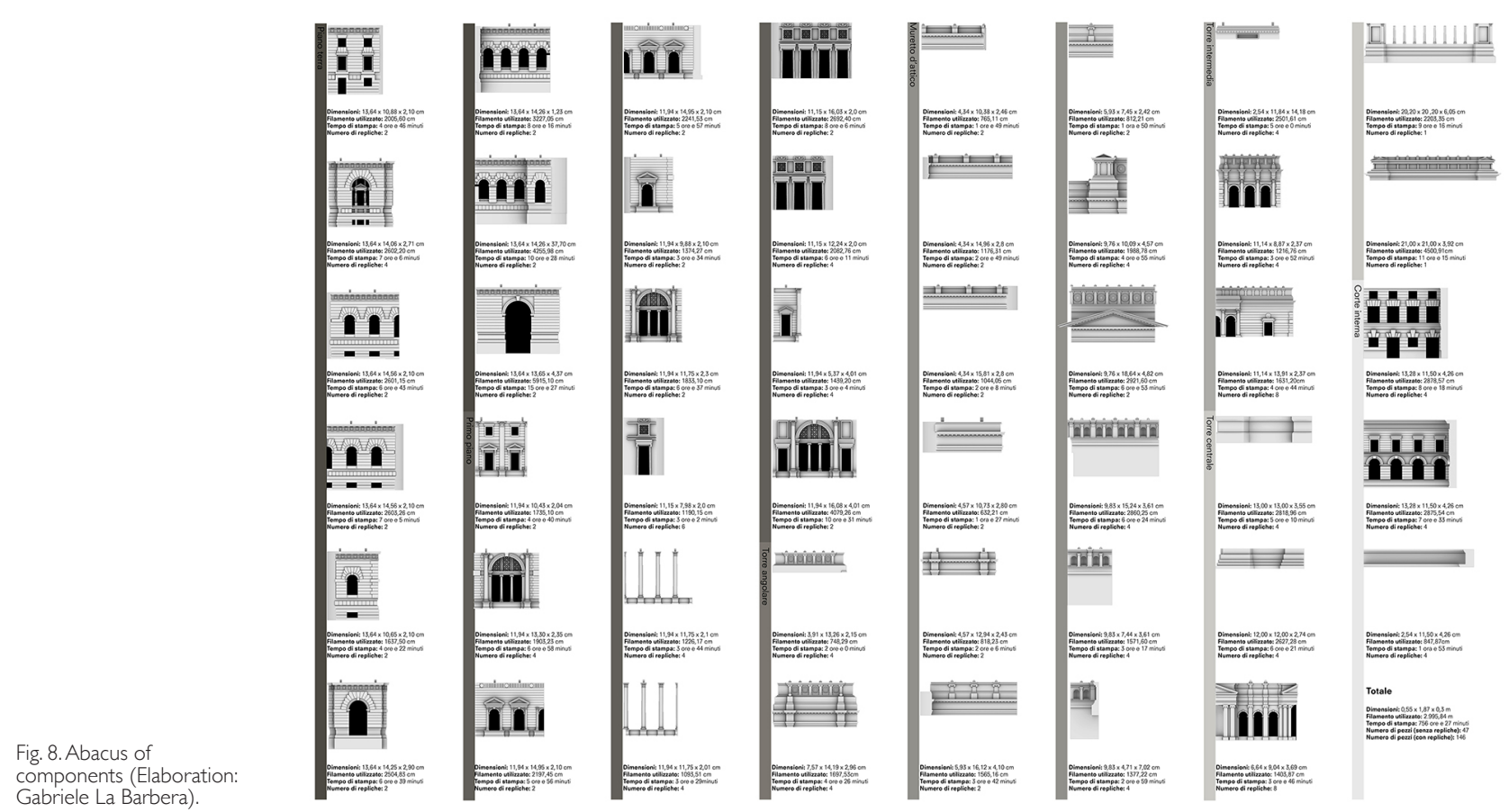




\section{Post-production, assembly and finishing}

The next phase concerned the post-production of 3D printing. The pieces have been subjected to the elimination of that layer of adhesion to the printing plate, which, in the case in question, was generated in brim [12] mode, and the removal of the supports, where necessary.

The pieces received a first surface smoothing to eliminate any imperfections and an assembly check. Where the juxtaposition of the elements was found to be correct, we proceeded to glue them with water-based acrylic glue, capable of guaranteeing sealing up to $60 \mathrm{~kg} / \mathrm{cm} 2$. As the gluing proceeded, the grouting was carried out both to regularize those portions of the surface that had micro-gaps, due, in some cases to the withdrawal of the PLA, and to fill the few visible joints.

The final phase was that of painting on primer, necessary to make the model homogeneous to cover the different shades of white of the filaments and the grouted portions. A pearly white was chosen, with acrylic colour passed with an airbrush, to obtain a neutral surface, given the lack of material information, both in the drawings and in the memories (figs. 10-12).

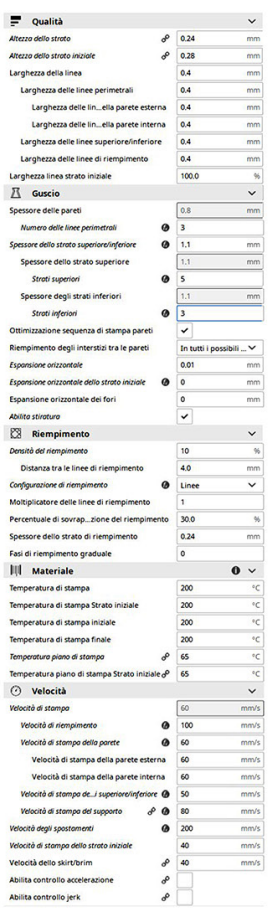

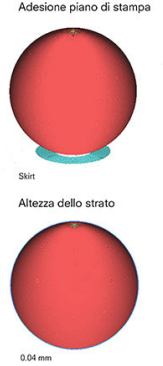
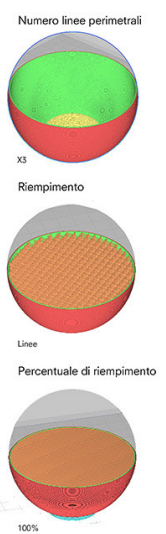

$100 \%$
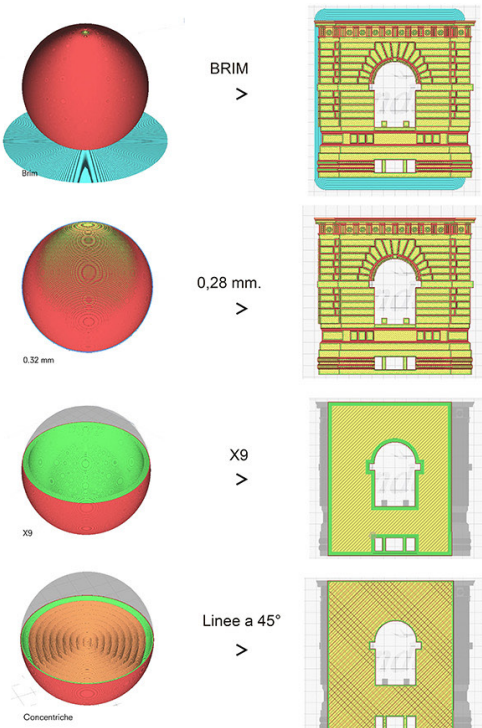

$\stackrel{\text { Linee a } 45}{>}$
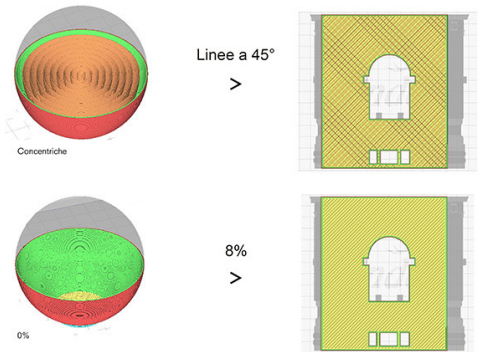

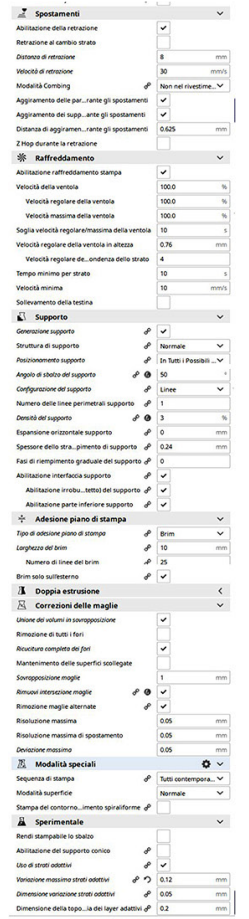

\section{Conclusions}

This work constitutes a further element of knowledge of this project of great historical value and offers the possibility of seeing the three-dimensionality of the facade, grasping its architectural quality and appreciating its classical language.

The model will be visible on permanent display at the Basile Endowment of the Architecture Department of the University of Palermo and will be included in the Miscellaneous fund of the Palermo Department of Architecture. 
Fig. 10. PLA model, overall view (Elaboration: Gabriele La Barbera).

Fig. 1 1. Model in PLA, monumental entrance (Elaboration: Gabriele La Barbera).
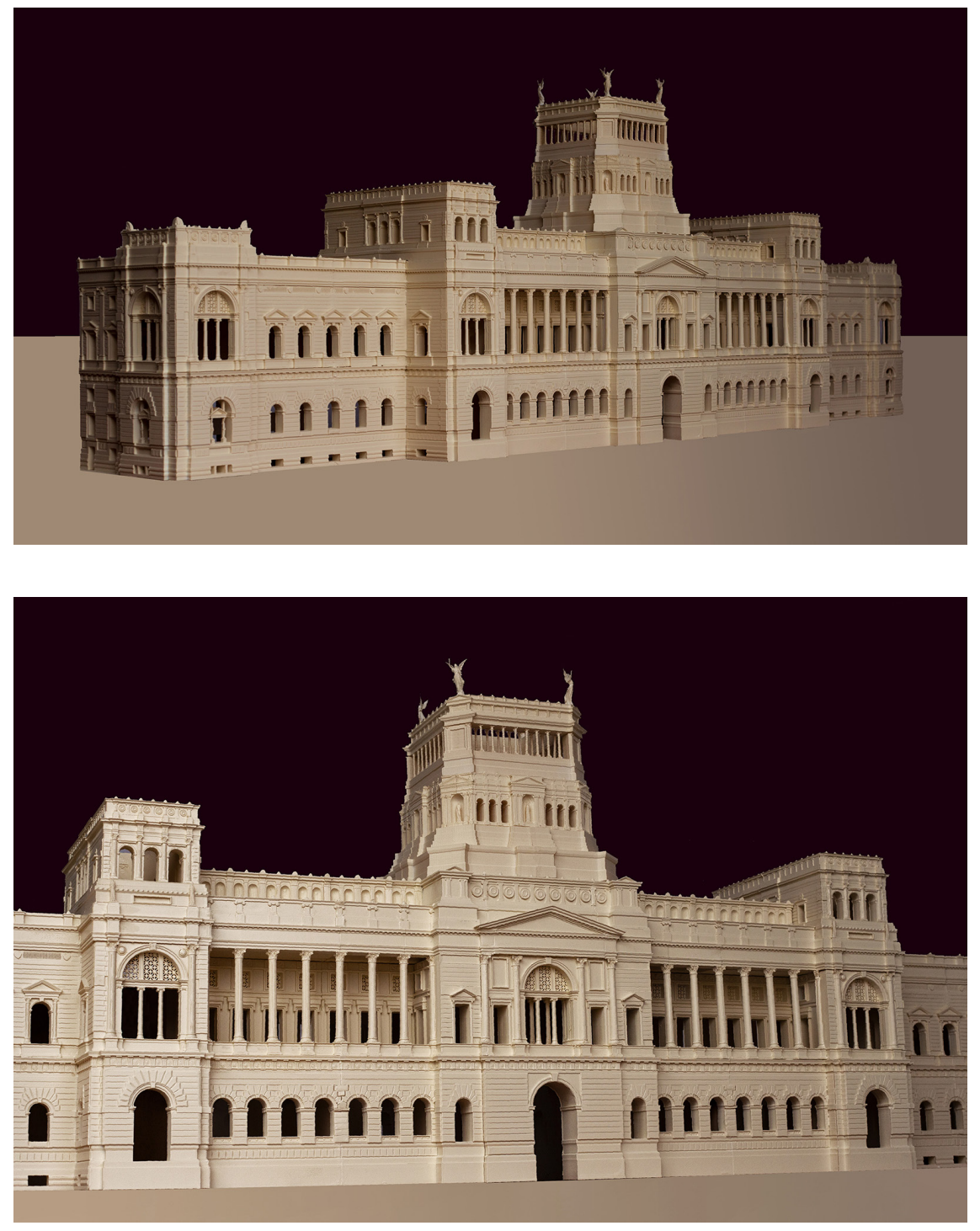

Fig. 12. PLA model, detail

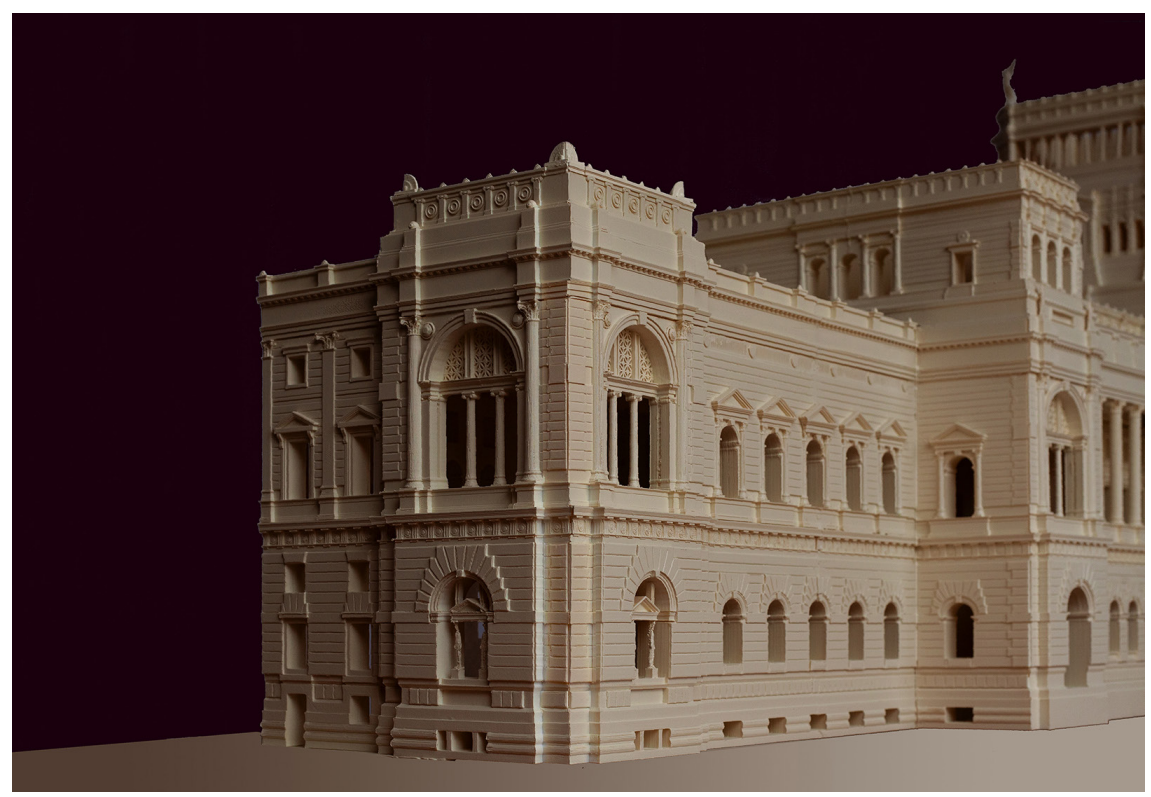




\section{Notes}

[I]The other awarded designers are Gaetano Moretti, Luigi Broggi and Giuseppe Sommaruga, Pier Paolo Quaglia Vincenzo Benvenuti, Enrico Ristori [Sessa, 2002, p. 58].

[2] About the architectural language of the building see Sessa, 2002, pp. 58-62.

[3] For an examination of the architectural language of Ernesto Basile see Sessa, 2002.

[4]There are three copies at the Basile Endowment of the Department of Architecture, collected in a booklet (Coll. Basile 42 [6]/2).

[5] The boards are $30 \mathrm{~cm}$ in size. $\times 38 \mathrm{~cm}$ which involves a reduction of the drawings in 1/692 scale.

[6] The NURBS model was carried out with the software Rhinoceros.

[7]The software used is Creality Ender 3 Pro.

[8] The software used is Ultimaker Cura.

[9] The function used is Complete re-stitching of holes and Union of overlapping volumes.

[ I0] By slicing we mean the generation of a G-Code that manages the information on the parameters necessary for the optimization of the printing process.

[I I] On the workflow of the modelling, setting and 3D printing process, see Bañón, Raspall, 2020.

[12] This mode ensures improved flatness and adhesion to the print bed, and easy removal of the part from the contours.

\section{References}

Avella F. (2020). Il secondo concorso per il Parlamento di Ernesto Basile. Analisi e ricostruzione congetturale. In Arena A. et al. (a cura di). Connettere. Un disegno per annodare e tessere. Atti del $42^{\circ}$ Convegno Internazionale dei Docenti delle Discipline della Rappresentazione/Connecting. Drawing for weaving relationships. Proceedings of the 42 th International Conference of Representation Disciplines Teachers, pp. I622-1643. Milano: Franco Angeli.

Bañón C, Raspall F. (2020). 3D Printing Architecture. Workflows, applications, and trends. Singapore: Springer.

Basile E. (I 890). Progetto per il palazzo del parlamento italiano nel concorso nazionale del I 889. Roma: Stabilimento Tipografico. Italiano.

Mauro E., Sessa E. (a cura di). (2000a). Giovan Battista Filippo Basile ed Ernesto Basile: settant'anni di Architetture: i disegni restaurati della Dotazione Basile, 1859-1929. Palermo: Novecento.

Mauro E., Sessa E. (a cura di). (2000b). Ernesto Basile a Montecitorio e i disegni restaurati della Dotazione Basile. Palermo: Novecento.

Mauro E., Sessa E. (2015). I disegni della Collezione Basile. Roma: Officina Edizioni.

Sessa E. (2002). Ernesto Basile. Dall'eclettismo classicista al modernismo. Palermo: Novecento.

\section{Authors}

Fabrizio Avella, Università degli Studi di Palermo, fabrizio.avella@unipa.it

To cite this chapter. Avella Fabrizio (2021). II secondo concorso per il Parlamento di Ernesto Basile. Criteri di modellazione e stampa 3D/The Second Competition for the Parliament Building in Rome by Ernesto Basile. 3D Modelling and Printing Criteria. In Arena A., Arena M., Mediati D., Raffa P. (a cura di). Connettere. Un disegno per annodare e tessere. Linguaggi Distanze Tecnologie. Atti del $42^{\circ}$ Convegno Internazionale dei Docenti delle Discipline della Rappresentazione/Connecting. Drawing for weaving relationship. Languages Distances Technologies. Proceedings of the 42 th International Conference of Representation Disciplines Teachers. Milano: FrancoAngeli, pp. 1978-1997. 